\title{
Breast Cancer 2013 - Interpretation of New and Known Data
}

\section{Mammakarzinom 2013 - Interpretation neuer und bekannter Daten}

Authors

Affiliations
M. P. Lux ${ }^{1}$, N. Maass ${ }^{2}$, F. Schütz ${ }^{3}$, I. Schwidde ${ }^{4}$, P. A. Fasching ${ }^{1}$, T. Fehm ${ }^{5}$, W. Janni ${ }^{6}$, S. Kümmel ${ }^{4}$, H.-C. Kolberg ${ }^{7}$, D. Lüftner ${ }^{8}$

The affiliations are listed at the end of the article.

Key words
breast cancer
treatment
local recurrence
metastases
trials
Schlüsselwörter
Mammakarzinom
B Behandlung
L Lokalrezidiv
Metastasen
- Studien

received 16.5.2013

revised 16.5.2013

accepted 16.5.2013

Bibliography

DOI http://dx.doi.org/

10.1055/s-0032-1328691

Geburtsh Frauenheilk 2013; 73 :

584-598 ๑ Georg Thieme

Verlag KG Stuttgart · New York . ISSN 0016-5751

\section{Correspondence}

Prof. Peter A. Fasching, MD

University Hospital Erlangen

Department of Gynecology and Obstetrics

Universitätsstraße 21-23

91054 Erlangen

peter.fasching@uk-erlangen.de

\section{Abstract \\ $\nabla$}

The treatment options and characteristics for therapeutic decisions for patients with primary and advanced breast cancer are becoming more and more numerous. New targeted therapies in combination with established chemotherapy regimens are expending the spectrum but potentially promising combinations do not also give a better result. The latest data from pharmacogenomics point to prognosis and predictive factors that take not only the properties of the tumour but also the hereditary genetic features of the patient into account. Current therapy decisions are thus based on a combination of classical clinical and modern molecular biomarkers. Health-economic aspects are also being taken into account more often, so that health-political considerations may also play a part. The present review article summarises parts of the results presented at the 2012 San Antonio Breast Cancer Symposia (SABCS), ESMO 2012 and St. Gallen 2013 together with new and important publications on the prevention of and therapy for breast cancer.

\section{Introduction \\ $\nabla$}

Therapy for patients with breast cancer has undergone marked changes in the last decade. The conscientious balancing of the invasiveness of an intervention in the human body against the benefits in regard to reduced mortality and recurrences has been continuously refined since the introduction of breast-preserving therapy with breast irradiation and since the introduction of chemotherapy. The aim of today's modern therapy is an exact adaption of the treatment not only to the aggressiveness of the disease but also to the

\section{Zusammenfassung}

$\nabla$

Die Behandlungsoptionen und die Charakteristika zur Therapieentscheidung der Patientin mit einem primären und fortgeschrittenen Mammakarzinom werden immer vielfältiger. Neue zielgerichtete Therapien in Kombination mit etablierten Chemotherapien erweitern das Spektrum, doch potenziell vielversprechende Kombinationen bringen nicht immer ein besseres Ergebnis. Neueste Daten aus der Pharmakogenomik weisen auf Prognose- und Prädiktivfaktoren hin, die nicht nur die Eigenschaften des Tumors, sondern auch die vererbbaren genetischen Eigenschaften der Patientin berücksichtigen. Die aktuelle Therapieentscheidung ist somit mittlerweile eine Kombination aus klassischerweise klinischen und modernen molekularen Biomarkern. Immer häufiger werden auch gesundheitsökonomische Aspekte berücksichtigt, sodass auch gesundheitspolitische Überlegungen eine Rolle spielen können. Diese Übersichtsarbeit fasst einen Teil der auf dem 2012 San Antonio Breast Cancer Symposion (SABCS), ESMO 2012 und St. Gallen 2013 behandelten Ergebnisse und aktuelle hochrangige Publikationen zur Prävention und Therapie der Patientin mit einem Mammakarzinom zusammen.

\section{Einleitung}

$\nabla$

Die Therapie der Patientin mit einem Mammakarzinom hat in den letzten Jahrzehnten eine deutliche Veränderung durchgemacht. Die gewissenhafte $\mathrm{Ab}-$ wägung von Invasivität des Eingriffs in den menschlichen Körper und Nutzen in Bezug auf reduzierte Sterblichkeit und Rückfallrate wurde seit der Einführung der brusterhaltenden Therapie mit Brustbestrahlung und seit Einführung der Chemotherapie immer weiter verfeinert. Ziele der modernen Therapie von heute sind die genaue Abstimmung der Therapie nicht nur auf die Aggressivität der Erkrankung, 
individual response to therapy and possible undesired side effects for the patient. This is guaranteed not only by the development of new drugs but also by the integration of individual biomarkers that can predict the efficacy and side effects of a drug. The overview presented here deals with topics based on the data presented at the last congress in San Antonio and against the background of the breast cancer conference in St. Gallen. In addition, important new developments in breast cancer research and therapy are included.

\section{Prevention}

In the framework of prevention of breast cancer marked advances have been achieved in Germany in the past 10 years with the implementation of mammography screening as well as counselling and early detection of family risk cases. In addition, our understanding of the breast cancer risk has increased in the last 10 years due to new molecular and clinical knowledge, some of which may shortly be tested in clinical practice [1]. Mammographic breast density has been established as one of the most important risk factors for breast cancer [2-4], and just recently 49 further genetic risk variants were discovered which will help in the prediction of breast cancer [5-10]. Some risk factors, such as mammographic breast density and a few genetic variants, can even be assigned to the risk for a special type of breast cancer or an elevated risk of recurrence [5,11-15].

\section{Local therapy}

In the last ten years in the field of local therapy major advances to improve the quality of life have been made. The introduction of breast-preserving therapy $[16,17]$ and the sentinal lymph node technique [18] has enabled many women to keep their breasts and spared them from lyphoedemas that 10 years ago occurred in up to $30 \%$ of the patients [19]. Also the most recent trials are aimed at minimising the side effects of local therapies. They are examining the shortening and reduction of irradiation and the implementation of sentinal lymph node removal in neoadjuvant therapy concepts.

\section{Possible reduction of local radiation therapy}

The START group has resented the 10-year follow-up data of the START-A and START-B studies [20]. The 5-year data had already shown that hypofractionation was not associated with an elevated radiation reaction or an increased risk of local recurrences. In START A the classical regime with 50 Gy in 25 fractions over 5 weeks was compared with two regimes of 41.6 or $39 \mathrm{~Gy}$ in 13 fractions over 5 weeks. In START B the gold standard was compared with $40 \mathrm{~Gy}$ in 15 fractions over 3 weeks. Both trials confirmed that the use of less than $50 \mathrm{~Gy}$ and less than 25 fractions did not lead to a higher toxicity or to a higher local failure. As a consequence, NICE has declared the therapy with $40 \mathrm{~Gy}$ in 15 fractions as the standard in Great Britain [20].

\section{Intraoperative radiotherapy}

The TARGIT study group has also just presented a report [21]. In the TARGIT-A trial, patients after BET were randomised either to a whole breast radiation or to an intraoperative radiation (IORT) with the Intrabeam ${ }^{\circledR}$. If post-operative risk factors were present in the IORT group then whole breast radiation was added at the end. Since the trial had recruited patients up to 2012 the followup times varied widely. The absolute difference in local recur- sondern auch auf das individuelle Therapieansprechen und mögliche unerwünschte Nebenwirkungen bei der Patientin. Dies wird nicht nur durch die Entwicklung von neuen Medikamenten, sondern auch durch die Integration von individuellen Biomarkern, welche die Effektivität und Nebenwirkungen eines Medikaments vorhersagen können, in moderne Studiendesigns gewährleistet. Die hier vorgestellte Zusammenfassung beschäftigt sich mit dem Thema vor dem Hintergrund der Daten, welche auf dem letzten Kongress in San Antonio vorgestellt wurden und vor dem Hintergrund der Brustkrebskonferenz in St. Gallen. Zusätzlich werden wichtige Entwicklungen in der Brustkrebsforschung und Brustkrebstherapie dargestellt.

\section{Prävention}

\section{$\nabla$}

Im Rahmen der Prävention des Mammakarzinoms sind in den letzten 10 Jahren in Deutschland mit der Implementierung des Mammografie-Screenings und der Übernahme der Beratung und Früherkennung von familiären Risikofällen deutliche Fortschritte gemacht worden. Aber auch beim Verständnis des Mammakarzinomrisikos sind in den letzten 10 Jahren neue molekulare und klinische Erkenntnisse gewonnen worden, die unter Umständen kurz vor dem Versuch der Anwendung in der klinischen Praxis stehen [1]. Die mammografische Dichte hat sich als einer der bedeutendsten Risikofaktoren für das Mammakarzinom etabliert [2-4], und kürzlich sind 49 weitere genetische Risikovarianten entdeckt worden, die helfen, das Brustkrebsrisiko besser vorherzusagen [5-10]. Manche Risikofaktoren wie die mammografische Dichte und einige genetische Varianten können sogar dem Risiko für spezielle Subtypen des Mammakarzinoms oder einem erhöhten Rückfallrisiko zugeordnet werden [5,11-15].

\section{Lokale Therapie}

In den letzten Jahrzehnten haben sich die größten Fortschritte zur Verbesserung der Lebensqualität auf dem Gebiet der lokalen Therapie ereignet. Die Einführung der brusterhaltenden Therapie $[16,17]$ und der Sentinel-Lymphknoten-Technik [18] konnte vielen Patientinnen die Brust retten und das Lymphödem, welches vor 10 Jahren noch bei bis zu 30\% der Patientinnen vorkam [19], ersparen. Auch die neuesten Studien arbeiten weiter daran, die Nebenwirkungen der Lokaltherapien zu minimieren. Sie beschäftigen sich mit der Verkürzung und Reduktion der Bestrahlung und der Implementierung der SentinelLymphknoten-Entfernung in neoadjuvante Therapiekonzepte.

\section{Mögliche Reduktion der lokalen Strahlentherapie}

Die START-Gruppe präsentierte die 10-Jahres-Nachbeobachtungsdaten der START-A- und der START-B-Studie [20]. Bereits die 5-Jahres-Daten hatten gezeigt, dass die Hypofraktionierung weder mit einer erhöhten Strahlenreaktion noch mit einem erhöhten Lokalrezidivrisiko verbunden ist. In der START A wurde das klassische Regime mit 50 Gray in 25 Fraktionen über 5 Wochen verglichen mit 2 Regimen von 41,6 oder 39 Gray in 13 Fraktionen über 5 Wochen, in der START B wurde der Goldstandard verglichen mit 40 Gray in 15 Fraktionen über 3 Wochen. Beide Studien bestätigten, dass die Verwendung von weniger als 50 Gray und weniger als 25 Fraktionen weder zu einer erhöhten Toxizität noch zu einem höheren lokalen Versagen führt. Als Konsequenz hat das NICE die Therapie mit 40 Gray in 15 Fraktionen zum Standard in Großbritannien erklärt [20].

\section{Intraoperative Strahlentherapie}

Ebenfalls aktuelle Daten wurden von der TARGIT-Studiengruppe berichtet [21]. In der TARGIT-A-Studie wurden Patientinnen nach BET entweder zu einer Ganzbrustbestrahlung oder zu einer intraoperati- 
rence rates was $2 \%$ to the disadvantage of IORT, however, this is below the predefined value for non-inferiority. For PR-positive patients this value was merely $0.18 \%$. For overall survival a trend towards better survival for the IORT group together with a significantly lower non-breast cancer-specific mortality. Of course, these results must be interpreted with caution, but they do suggest that for selected patients the waiving of whole breast irradiation is also an option.

\section{Sentinal lymph node removal as neoadjuvant option}

Concerning sentinal lymph node excision (SLNB) after neoadjuvant chemotherapy (NAC), there are two new trials, the ACOSOG-Z1071 study and the German SENTINA study [22,23]. In the ACOSOG-Z1071 trial patients with affected lymph nodes who received an SLNB with subsequent axilla dissection (AD) after the chemotherapy were enrolled. The positive predictive value for SNLB amounted to $84 \%$, the false-negative rate was $12.8 \%$. Thus, the trial did not reach the predefined end point of $10 \%[22]$.

The SENTINA trial had a similar but much more complex design [23]. Patients with clinically unremarkable lymph nodes before NAC received a pretherapeutic SLNB, in cases with positive SLN a repeat SNLB with axilla dissection was performed after NAC. Patients with clinically affected lymph nodes received only SLNB + AD when the lymph nodes were unremarkable after NAC, in cases with still remarkable lymph nodes a classical axilla dissection was performed. The detection rate of the pretherapeutic SLNB was excellent with $99.1 \%$. The post-therapeutic false-negative rate in patients with pretherapeutic positive SLNB amounted to $51.6 \%$, the detection rate was $60.8 \%$. The detection rate in the group with pretherapeutic affected LN was $80.1 \%$, the false-negative rate $14.2 \%$. The authors concluded that SLNB represents an excellent staging option before NAC for patients with clinically unremarkable lymph nodes [23]. The detection rates and falsenegative rates after NAC are not acceptable so that SLNB after NAC is not a suitable procedure for renewed LN staging.

\section{Neoadjuvant options}

A marked leap forward in our knowledge with regard to the efficacy of therapeutic options and their effects on long-term survival has been achieved in the past years through therapeutic studies in the neoadjuvant situation [24]. Also knowledge regarding biomarkers has been clearly advanced by neoadjuvant therapeutic studies [25-27]. An international comparison reveals that most of these trials have been carried out in the German-speaking region [28-37]. In the past 12 months there has been an appreciable increase in our knowledge.

The prospective randomised FemZone study has reported on an analysis of 168 patients who received a neoadjuvant endocrine therapy with letrozole. One half of the patients additionally underwent a therapy with zoledronate (4 mg q4w). Although the response rate in the zoledronate group was higher (complete remission [CR]: $3.7 \%$, partial remission [PR]: $42.0 \%$ ) than in the monotherapy group (CR 1.3\%, PR 33.3\%), the differences were not statistically significant $(\mathrm{p}=0.106)$ [38].

\section{Validity of pCR - a metaanalysis}

With the huge amount of data on neoadjuvant chemotherapy and the good correlation with pathological complete remission (pCR), the question arises as to whether this target criterion could possibly be used to speed up the approval of drugs, similar to the case of treatment for high blood pressure in order to avoid later ven Bestrahlung (IORT) mit dem Intrabeam ${ }^{\circledR}$ randomisiert. Ergaben sich in der IORT-Gruppe postoperativ Risikofaktoren, wurde eine Ganzbrustbestrahlung angeschlossen. Da die Studie bis 2012 rekrutiert hat, waren die Follow-up-Zeiten sehr unterschiedlich. Der absolute Unterschied in den Lokalrezidivraten lag bei $2 \%$ zuungunsten der IORT, dies lag allerdings unter dem vorher definierten Wert für die Nichtunterlegenheit. Bei PR-positiven Patientinnen betrug dieser Wert lediglich 0,18\%. Für das Gesamtüberleben zeigte sich ein Trend zu einem besseren Überleben für die IORT bei einer signifikant geringeren, nicht brustkrebspezifischen Sterblichkeit. Selbstverständlich müssen diese Ergebnisse noch mit Vorsicht interpretiert werden, sie weisen aber darauf hin, dass für ausgewählte Patientinnen der Verzicht auf eine Ganzbrustbestrahlung eine Option darstellt.

\section{Sentinel-Lymphknoten-Entfernung in der Neoadjuvanz}

Zur Sentinel-Lymphknoten-Entfernung (SLNB) nach neoadjuvanter Chemotherapie NAC gibt es 2 neue Studien, die ACOSOG-Z1071-Studie und die deutsche SENTINA-Studie [22,23]. In die ACOSOG-Z1071Studie wurden Patientinnen mit befallenen Lymphknoten eingeschlossen, die nach der Chemotherapie eine SLNB mit anschließender Axilladissektion (AD) erhielten. Der positive Vorhersagewert für die SLNB betrug $84 \%$, die Falsch-negativ-Rate lag bei $12,8 \%$. Damit erreichte die Studie nicht den vorher definierten Endpunkt von $10 \%$ [22].

Ein ähnliches, wenn auch ungleich aufwendigeres Design hatte die SENTINA-Studie [23]. Patientinnen mit klinisch unauffälligen Lymphknoten vor NAC erhielten eine prätherapeutische SLNB, bei positiven SLN schloss sich nach der NAC eine erneute SLNB mit Axilladissektion an. Patientinnen mit klinisch befallenen Lymphknoten erhielten nur eine SLNB + AD, wenn die Lymphknoten nach NAC unauffällig waren, bei weiter auffälligen Lymphknoten wurde eine klassische Axilladissektion durchgeführt. Die Detektionsrate der SLNB prätherapeutisch war mit 99,1\% exzellent. Die posttherapeutische Falsch-negativ-Rate bei Patientinnen mit prätherapeutisch positivem SLNB lag bei $51,6 \%$, die Detektionsrate bei 60,8\%. Die Detektionsrate in der Gruppe mit prätherapeutisch befallenen LK war $80,1 \%$, die Falsch-negativ-Rate $14,2 \%$. Die Autoren folgern, dass die SLNB eine exzellente StagingMöglichkeit vor NAC für Patientinnen mit klinisch unauffälligen Lymphknoten darstellt [23]. Die Detektionsraten und die Falsch-negativ-Raten nach NAC sind inakzeptabel, sodass die SLNB nach NAC keine geeignete Prozedur zum erneuten LK-Staging ist.

\section{Neoadjuvanz}

Durch Therapiestudien in der neoadjuvanten Situation ist in den letzten Jahren ein deutlicher Wissenssprung in Bezug auf Erkenntnisse der Wirksamkeit von Therapien und deren Effekt auf das Langzeitüberleben gelungen [24]. Auch die Erkenntnisse in Bezug auf Biomarker konnte durch neoadjuvante Therapiestudien deutlich gefördert werden [25-27]. Im internationalen Vergleich wird klar, dass ein großer Teil dieser Studien im deutschsprachigen Raum durchgeführt werden [28-37]. In den letzten 12 Monaten konnte ein deutlicher Informationszugewinn verzeichnet werden.

Die prospektiv randomisierte FemZone-Studie berichtete von einer Analyse von 168 Patientinnen, die mit einer neoadjuvanten endokrinen Therapie mit Letrozol behandelt wurden. Die Hälfte der Patientinnen wurde zusätzlich mit einer Zoledronat-Therapie (4 mg q4w) therapiert. Die Ansprechraten in der Zoledronat-Gruppe waren zwar höher (Komplettremission [CR]: 3,7\%, partielle Remission [PR]: $42,0 \%$ ) als in der Monogruppe (CR 1,3\%, PR 33,3\%), welches aber keine statistische Signifikanz erreichte $(p=0,106)[38]$ 
vascular diseases. For this reason the American Food and Drug Administration (FDA) performed a metaanalysis of about 12000 patients with participation of German groups [39]. The prognostic relevance of pCR on recurrence-free survival (HR 0.48, $\mathrm{p}<0.001$ ) and overall survival (HR 0.48, $\mathrm{p}<0.001$ ) was unequivocally confirmed. A significant difference between the various definitions of pCR (with or without DCIS parts) could not be demonstrated. With regard to tumour biology, the study led to the conclusion that pCR has more prognostic relevance when the tumour is more aggressive and more sensitive to chemotherapy. One of the points that has, at present, caused the FDA to take a more reserved position is that it could not be determined to what extent the prognosis improves when the $\mathrm{pCR}$ on comparison of two therapies improves by a specific percentage. Larger subgroup analysis may possibly help to clarify this point in the future.

\section{Neoadjuvant chemotherapy for very young patients with breast cancer}

With the increasing amount of data on neoadjuvant options, the data are becoming more and more stable so that even subgroups such as young women can be better assessed in separate subgroup analyses. It is known that young women under the age of 40 years with breast cancer have a poorer prognosis than those who become ill in later years. In addition, they also appear to have a different molecular pattern [40]. According to a study presented by FDA at SABCS 2012 which pooled the data from 8 trials with 8949 patients, for young women up to the age of 35 years ( $n=704$ ) with operable or locally advanced but not metastatic breast cancer a pathological complete remission with ypT0 and ypNO was achieved after neoadjuvant chemotherapy in $23.6 \%$, which is significantly more often than for older patients aged 51 years or more $(n=4078)$ with $13.5 \%(p=0.002)$ [41].

Age represents an independent predictive factor for the achievement of pCR. However, this effect is limited to the subgroups of triple-negative cancer $(\mathrm{TNBC})(\mathrm{p}=0.004)$ and those with breast cancer of the luminal type (hormone receptor-positive, HER2 negative $)(p=0.013)$, whereby the very young women exhibit a special tumour biology with a larger proportion of triple-negative (TNBC) and a smaller proportion of luminal A breast cancer types than the women older than 51 years ( 32 vs. $21 \%$ for TNBC and 35 vs. $51 \%$ for luminal A) [41].

Not only disease-free survival (DFS) but also local recurrencefree survival (LRFS) were significantly poorer for the very young patients up to the age of 23 years than those aged between 36 and 50 years (DFS: HR $0.83,95 \% \mathrm{CI} 0.70-0.98, \mathrm{p}=0-031$; LRFS: HR $0.74,95 \%$ CI $0.58-0.95 ; p=0.018$ ) or, respectively, for women over 51 years of age (DFS: $p=0.022$; LRFS: $p=0.00018$ ) [41]

If a pCR is not achieved, patients of all age groups have significantly poorer DFS and LRFS, while the best DFS is found for women under the age of 35 years for whom pCR was achieved.

The surprising result from these data is that women with luminal-A tumours (HR-positive, HER2-negative), for whom PCR was achieved, exhibit a trend towards an improved DFS in comparison to those without $\mathrm{pCR}$. However, this was significant only for the $36-50$ years age group $(p=0,008)[41]$.

The authors conclude that neoadjuvant chemotherapy can be considered for very young patients including those with HR-positive and HER2-negative breast cancer [41].

\section{Validität der $\mathrm{pCR}$ - eine Metaanalyse}

Bei der Fülle der Daten zur neoadjuvanten Chemotherapie und der guten Korrelation der kompletten pathologischen Remission stellt sich die Frage, ob dieses Zielkriterium nicht benutzt werden könnte, um Medikamente möglicherweise schneller zuzulassen, ähnlich wie bei der Behandlung des Bluthochdrucks zur Vermeidung von späteren Gefäßerkrankungen. Aus diesem Grund hat die amerikanische Zulassungsbehörde Food and Drug Administration (FDA) eine Metaanalyse von etwa 12000 Patientinnen unter Beteiligung der deutschen Arbeitsgruppen durchgeführt [39]. Die prognostische Relevanz der pCR auf rezidivfreies Überleben (HR 0,48, p < 0,001) und Gesamtüberleben (HR 0,48, $\mathrm{p}<0,001$ ) konnte zweifelsfrei bestätigt werden. Ein signifikanter Unterschied zwischen den verschiedenen Definitionen von PCR (mit oder ohne DCIS-Anteile) konnte nicht gezeigt werden. Bezüglich der Tumorbiologie kam die Studie zu dem Ergebnis, dass die $\mathrm{pCR}$ umso prognostisch relevanter ist, je aggressiver und chemotherapiesensibler der Tumor ist. Einer der Punkte, der die FDA zurzeit noch zu einer zurückhaltenden Position gebracht hat, ist, dass nicht nachgewiesen werden konnte, um welches Ausmaß sich die Prognose verbessert, wenn sich die PCR beim Vergleich zweier Therapien um einen gewissen Prozentsatz verbessert. Ggf. bringen größere Subgruppenanalysen hier in Zukunft mehr Klarheit.

\section{Neoadjuvante Chemotherapie bei sehr jungen}

\section{Mammakarzinompatientinnen}

Durch die zunehmende Datenfülle in der Neoadjuvanz werden die Daten immer stabiler, um auch Untergruppen wie junge Frauen in getrennten Subgruppenanalysen besser einschätzen zu können. Es ist bekannt, dass junge Frauen mit einem Mammakarzinom unter 40 Jahren eine schlechtere Prognose haben als Patientinnen, die in höherem Alter erkranken. Außerdem scheinen sie ein anderes molekulares Muster zu haben [40]. Gemäß einer beim SABCS 2012 von der amerikanischen Zulassungsbehörde FDA vorgestellten Untersuchung, bei der Daten aus 8 Studien mit 8949 Patientinnen gepoolt wurden, konnte bei sehr jungen Frauen im Alter bis 35 Jahre $(n=704)$ nach neoadjuvanter Chemotherapie bei operablem oder lokal fortgeschrittenem, nicht metastasiertem Mammakarzinom mit 23,6\% signifikant häufiger eine pathologische Komplettremission (pCR) mit ypT0 und ypNO erreicht werden als bei älteren Patientinnen ab 51 Jahren $(\mathrm{n}=4078)$ mit $13,5 \%(\mathrm{p}=0,002)$ [41].

Das Alter stellte einen unabhängigen prädiktiven Faktor für das Erreichen einer pCR dar. Dieser Effekt beschränkte sich jedoch auf die Subgruppen der triple-negativen (TNBC) $(p=0,004)$ und der Mammakarzinome vom luminalen Typ (hormonrezeptorpositiv, HER2-negativ) $(p=0,013)$, wobei die sehr jungen Frauen eine besondere Tumorbiologie mit einem größeren Anteil von triple-negativen (TNBC) und einem kleineren Anteil von Luminal-A-Mammakarzinomtypen als die Frauen ab 51 Jahren aufwiesen ( 32 vs. $21 \%$ für TNBC und 35 vs. $51 \%$ für Luminal A) [41].

Sowohl das krankheitsfreie Überleben (DFS) als auch das lokalrezidivfreie Überleben (LRFS) fielen für die sehr jungen Patientinnen bis 35 Jahre signifikant schlechter aus als für diejenigen zwischen 36 und 50 Jahren (DFS: HR 0,83, 95\%-KI 0,70-0,98, p=0,031; LRFS: HR 0,74, $95 \%$ KI $0,58-0,95 ; p=0,018)$ bzw. für Frauen ab 51 Jahren (DFS: $\mathrm{p}=0,022 ;$ LRFS: $\mathrm{p}=0,00018)[41]$.

Bei Nichterreichen einer pCR resultierte für die Patientinnen aller Altersgruppen ein signifikant schlechteres DFS und LRFS, wohingegen das beste DFS die Frauen unter 35 Jahren erreichten, bei denen eine pCR erzielt werden konnte.

Das überraschende Resultat dieser Daten ist, dass sich bei den Frauen mit Luminal-A-Tumoren (HR-positiv, HER2-negativ), die eine pCR erreichen konnten, ein Trend für ein verbessertes DFS im Vergleich zu 


\section{Adjuvant therapy}

Bevacizumab in the adjuvant therapy

for triple-negative patients

Since bevacizumab has shown positive results in some trials and null results in others, the question as to which patients will benefit especially well from therapy with the angiogenesis inhibitor bevacizumab is still of major significance. Within the prospective randomised phase III trial BEATRICE, the one-year add-on administration of bevacizumab after adjuvant anthracyline- and/or taxane-containning chemotherapy for triple-negative patients was examined [42]. Altogether, 2591 patients were randomised. The 3 -year rate of IDFS (invasive disease-free survival) was $83.7 \%$ in the group with bevacizumab versus $82.7 \%$ in the group without an angiogenesis inhibitor [42]. Subgroup analyses also did not reveal an unequivocal signal for the various patient populations. The added biomarker examination, in contrast to previous data for metastatic situations (AVADO, AVEREL), could not identify baseline pVEGF $A$ as a predictive factor for a subgroup [43]. Merely a small group with high baseline values of pVEGFR-2 appeared to benefit from the addition of bevacizumab. Other markers that could predict a response to bevacizumab $[44,45]$ have not yet been investigated in this collective.

\section{Dose dense chemotherapy - ETC scheme}

At the San Antonio Breast Cancer Symposium 2012 also the 10year DFS and OS data of the German ETC trial were presented [46]. Also after 10 years there was a significant benefit for patients who were randomised in the dose dense, dose escalated therapy arm (OS: 69 vs. 59\%). With regard to the administration of erythropoietin, a negative influence on survival could not be observed. Thus, according to the authors, the ETC scheme may be considered as a possible standard therapy for patients with $\geq 4$ affected lymph nodes.

\section{Chemotherapy in cases of local recurrence}

Within the framework of an international intergroup trial (chemotherapy as adjuvant for locally recurrent breast cancer), it was shown in the generally usual clinical routine that patients with aggressive tumour biology (significant main effect by ER-) may profit from an expanded adjuvant chemotherapy even in cases of local recurrence (5-year OS: $88 \%$ with CTX vs. $76 \%$ without CTX; 0 Fig. 1). Unfortunately as a result of the low recruitment the trial was terminated at 162 randomised patients so that specific subgroup analyses to develop further hypotheses are difficult [47]. Accordingly, especially in the case of hormone receptor-negative patients with local recurrence, a postoperative chemotherapy should be recommended in future, this option is now also supported by the current AGO recommendations.

\section{Endocrine therapy}

Earlier studies have not demonstrated any benefit from the prolonged tamoxifen therapy. In an actual analysis of the ATLAS trial (adjuvant tamoxifen - longer against shorter $-\mathrm{n}=6846$ patients) a significant relative risk reduction of $21 \%$ referred to the overall survival was demonstrated for the extended 10-year therapy with tamoxifen as compared to the standard therapy duration of 5 years ( $\odot$ Fig. 2). Patients should be informed of the potential advantage of this treatment strategy over 10 years [48].

In a current subgroup analysis of the known BIG-1-98 trial (tamoxifen vs. letrozole vs. sequential therapy), the question of the therapeutic effect of letrozole compared to that of tamoxifen in histological subgroups (lobular vs. ductal) was analysed. In the denjenigen ohne eine $\mathrm{pCR}$ zeigte. Signifikant war dieser hier jedoch nur in der Altersgruppe der 36-50-Jährigen ausgefallen $(p=0,008)$ [41].

Die Autoren schlussfolgerten, dass für die sehr jungen Patientinnen eine neoadjuvante Chemotherapie erwogen werden kann, auch für diejenigen mit HR-positivem und HER2-negativem Mammakarzinom [41].

\section{Adjuvante Therapie}

Bevacizumab in der adjuvanten Therapie

bei triple-negativen Patienten

Nachdem es mit Bevacizumab einige positive und einige Null-ResultStudien gab, ist die Frage, welche Patientinnen besonders gut von einer Therapie mit dem Angiogenesehemmer Bevacizumab profitieren, nach wie vor von besonderer Bedeutung. Innerhalb der prospektiv randomisierten Phase-III-Studie BEATRICE wurde die zusätzliche 1-jährige Gabe von Bevacizumab nach adjuvanter anthrazyklinund/oder taxanhaltiger Chemotherapie bei triple-negativen Patientinnen untersucht [42]. Insgesamt wurden 2591 Patientinnen randomisiert. Die 3-Jahres-Rate des IDFS (invasive disease free survial) war in der Gruppe mit Bevacizumab 83,7 vs. 82,7\% ohne Angiogenesehemmer [42]. Auch die Subgruppenanalyse zeigte kein eindeutiges Signal für die verschiedenen Patientenpopulationen. Die additive Biomarkeruntersuchung konnte, entgegen vorheriger Daten aus der metastasierten Situation (AVADO, AVEREL) Baseline pVEGF A nicht als prädiktiven Faktor für eine Subgruppe identifizieren [43]. Lediglich eine kleine Gruppe mit hohen Baseline-Werten von pVEGFR-2 schienen von der Hinzunahme des Bevacizumab zu profitieren. Weitere Marker, die ein Bevacizumab-Ansprechen vorhersagen könnten [44, 45], sind in diesem Kollektiv noch nicht untersucht worden.

\section{Dosisdichte Chemotherapie - ETC-Schema}

Auf dem San Antonio Breast Cancer Symposium 2012 wurden ebenfalls die 10-Jahres-DFS- und -OS-Daten der deutschen ETC-Studie vorgestellt [46]. Auch nach 10 Jahren zeigte sich ein signifikanter Vorteil für Patienten, die in den dosisdichten, dosiseskalierten Therapiearm randomisiert wurden (OS: 69 vs. 59\%). Bezüglich der Gabe des Erythropoetins konnte in dieser Studie kein negativer Einfluss auf das Überleben beobachtet werden. Damit ist laut Autoren das ETCSchema als eine mögliche Standardtherapie bei Patienten mit $\geq 4$ befallenen Lymphknoten anzusehen.

\section{Chemotherapie beim Lokalrezidiv}

Im Rahmen einer internationalen Intergroup-Studie (Chemotherapy as Adjuvant for Locally Recurrent Breast Cancer) ließ sich die allgemein übliche klinische Routine nachweisen, dass Patienten mit einer aggressiven Tumorbiologie (signifikanter Haupteffekt bei ER-) auch im Lokalrezidivfall von einer erweitert adjuvanten Chemotherapie profitieren (5-Jahres-OS: $88 \%$ mit CTX vs. $76 \%$ ohne CTX; - Abb. 1). Leider wurde aufgrund der geringen Rekrutierung die Studie bei 162 randomisierten Patienten geschlossen, sodass spezifische Subgruppenanalysen zur weiteren Hypothesengenerierung schwierig sind [47]. Besonders bei hormonrezeptornegativen Patientinnen mit Lokalrezidiv sollte deshalb zukünftig eine postoperative Chemotherapie empfohlen werden, was nun auch durch die aktuellen AGOEmpfehlungen unterstützt wird.

\section{Endokrine Therapie}

Frühere Studien haben keinen Vorteil für die verlängerte Tamoxifentherapie gezeigt. In der aktuellen Analyse der ATLAS-Studie (Adjuvant tamoxifen - Longer against Shorter $-\mathrm{n}=6846$ Pat.) konnte unter der erweiterten 10-jährigen Therapie mit Tamoxifen eine signifikan- 


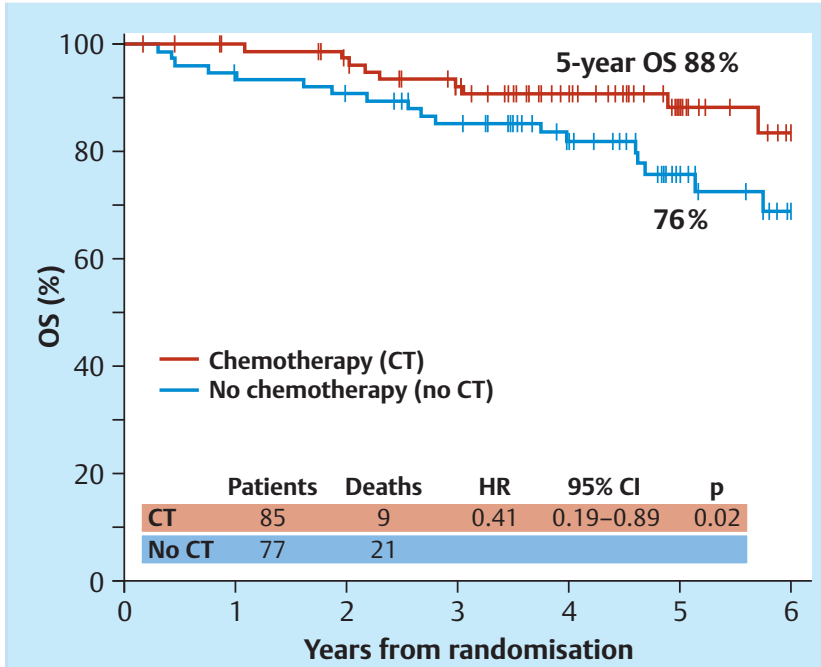

Fig. 1 Overall survival in the CALOR study (after [47]).

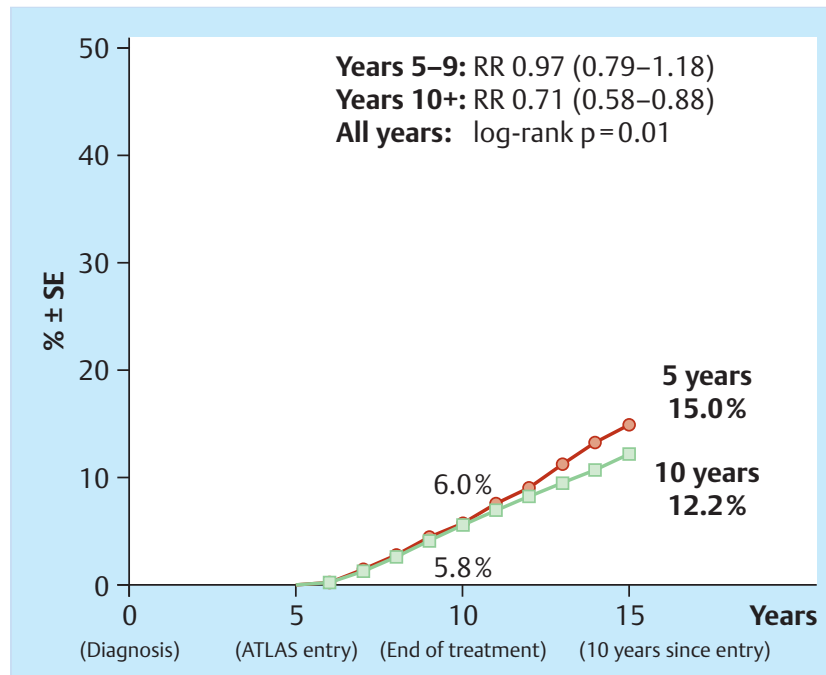

Fig. 2 Overall mortality in the ATLAS trial (modified after [48]). upfront therapy with letrozole, a significant benefit for the lobular subtype as compared to the sole administration of tamoxifen was demonstrated (DFS: 82 vs. 66\%; HR 0.48). A comparison with the sequential therapy (tamoxifen + letrozole) was not presented [49].

\section{Targeted therapy with trastuzumab}

The data already presented at the ESMO in Vienna concerning the HERA (12 vs. 24 months trastuzumab; $n=3404$, 8 years followup) and PHARE trials ( 12 vs. 6 months; $n=3384$ ) confirmed the current standard administration of 18 doses over 12 months (summarised in [50]). A doubling of therapy duration in the framework of the HERA trial did not show any further survival benefit (HR 1.05). Also within a non-inferiority design, randomised PHARE trial (aim: HR not larger than 1.15) the reduced therapy duration with trastuzumab for 6 months did not reveal a comparable efficacy in the entire population (HR 1.28). In the subgroup analysis, above all ER-negative patients who were treated sequentially and only for 6 months exhibited a marked disadvantage. The evaluations of further trials (PERSEPHONE, SHORTER SOLD) that also examine the question of a shortened therapy duration are not yet available $[51,52]$.

\section{New treatment options in the metastatic situation Bevacizumab in combination with endocrine therapy without additional benefit}

The LEA trial on the combination of bevacizumab with an endocrine therapy (aromatase inhibitor or fulvestrant) in the first-line treatment of metastatic breast cancer ended with negative results [74]. In this trial 380 hormone-receptor positive, HER-2/ neu-negative patients were randomised either to endocrine therapy $(n=189)$ or endocrine therapy + bevacizumab (15 mg/ $\mathrm{kg} ; \mathrm{n}=191)$. Primary endpoint was again progression-free survival (PFS), which was numerically, but not significantly, improved with the combination of bevacizumab plus endocrine therapy (18.4 vs. 13.8 months, HR 0.83, 95\% CI 0.65-1.06; $\mathrm{p}=0.14)$. On the other hand there were markedly more haematological and also non-haematological side effects. te relative Risikoreduktion von $21 \%$ bezogen auf das Gesamtüberleben gegenüber der Standardtherapiedauer von 5 Jahren nachgewiesen werden ( $\bullet$ Abb. 2). Patienten sollten hinsichtlich potenzieller Vorteile dieser Behandlungsoption über 10 Jahre aufgeklärt werden [48].

In einer aktuellen Subgruppenanalyse der bekannten BIG-1-98-Studie (Tamoxifen vs. Letrozol vs. sequenzielle Therapie) wurde die Frage des Therapieeffekts von Letrozol gegenüber Tamoxifen bei histologischen Subgruppen (lobulär vs. duktal) analysiert. In der UpfrontTherapie mit Letrozol konnte ein signifikanter Vorteil für den lobulären Subtyp gegenüber der alleinigen Gabe von Tamoxifen (DFS: 82 vs. $66 \%$; HR 0,48) gezeigt werden. Ein Vergleich gegenüber der sequenziellen Therapie (Tamoxifen + Letrozol) wurde nicht dargestellt [49].

\section{Zielgerichtete Therapie mit Trastuzumab}

Die bereits beim ESMO in Wien gezeigten Daten der HERA- (12 vs. 24 Monate Trastuzumab; $\mathrm{n}=3404$, 8-Jahres-Follow-up) und PHARE-Studie (12 vs. 6 Monate; $\mathrm{n}=3384$ ) konnten die derzeitige Standardapplikation von 18 Gaben über 12 Monate bestätigen (zusammengefasst in [50]). Die Verdopplung der Therapiedauer im Rahmen der HERA-Studie zeigte keinen weiteren Überlebensvorteil $(H R=1,05)$. Auch die innerhalb eines Non-Inferiority-Designs randomisierte PHARE-Studie (Ziel: HR nicht größer 1,15) konnte durch eine verkürzte Therapiedauer von Trastuzumab auf 6 Monate eine vergleichbare Effektivität in der Gesamtpopulation nicht nachweisen (HR 1,28). In der Subgruppenanalyse hatten v.a. ER--Patientinnen, die sequenziell und nur 6 Monate therapiert wurden, einen deutlichen Nachteil. Die Auswertungen weiterer Studien (PERSEPHONE, SHORTER SOLD), die diese Fragestellung einer verkürzten Therapiedauer untersuchen, stehen noch aus $[51,52]$.

\section{Neue Behandlungsoptionen in der}

metastasierten Situation

Bevacizumab in Kombination mit endokriner Therapie ohne zusätzlichen Nutzen

Mit negativen Ergebnissen endete die LEA-Studie zur Kombination von Bevacizumab mit einer endokrinen Therapie (Aromatasehemmer oder Fulvestrant) in der First-Line-Behandlung des metastasierten Mammakarzinoms [74]. In der Studie wurden 380 hormonrezeptorpositive, HER2/neu-negative Patientinnen zu entweder endokriner 


\section{More data on eribulin}

In a randomised phase III trial $(\mathrm{n}=1102)$, eribulin was compared with capecitabin in patients with metastatic breast cancer also in earlier stages as the as yet approved therapy lines [75]. Primary endpoints were overall survival (OS) and progression-free survival (PFS). In the entire trial population a numerical trend towards an improvement of OS was seen under eribulin (15.9 vs. 14.5 months; $p=0.056$ ). PFS was not prolonged in comparison to capecitabin (4.1 vs. 4.2 months; $p=0.305$ ). In an explorative subgroup analysis it was seen that patients with HER-2/neu-negative tumours $(\mathrm{n}=755)$ may have had a benefit. For the latter, eribulin prolonged the overall survival from 13.5 to 15.9 months (HR 0.838). For triple-negative tumours an unplanned analysis revealed a prolongation of OS from 9.4 to as much as 14.4 months (HR 0.70).

\section{Update of the CONFIRM trial:}

fulvestrant $500 \mathrm{mg}$ vs. fulvestrant $250 \mathrm{mg}$

At the SABCS 2012, the follow-up analysis of the CONFIRM trial after $75 \%$ deaths was presented [53]. The mean overall survival amounted to 26.4 months for fulvestrant $500 \mathrm{mg}$ and 22.3 months for fulvestrant $250 \mathrm{mg}$ (HR $0.81,95 \%$ CI 0.69-0.96; $p=0,016$ ). This benefit was not associated with an increased toxicity; altogether there were no clinically relevant differences in the safety profiles between the two treatment groups. Ultimately these results confirm the known positive dose-efficacy relationship of fulvestrant as had been shown in early trials with fulvestrant.

BOLERO-2 trial: significant prolongation

of PFS in all subgroups

In January 2012 the first analysis of the BOLERO-2 trial was published in full [54]. The addition of everolimus to a therapy with exemestan exhibited a clear improvement in the progressionfree survival. The final analysis of the phase-III BOLERO-2 trial revealed a mean progression-free survival (PFS) of 11 months under treatment with everolimus in combination with exemestan for postmenopausal patients with advanced, hormone receptor-positive, HER2-negative breast cancer [55]. At the SABCS 2012 the data for predefined subgroups were presented in the central evaluation. All patients benefited significantly with regard to mean PFS from the therapy with everolimus plus exemestan (HR 0.45; 95\% CI: 0.38-0.54; p<0.0001) - independent of age, number of previous therapies, as well as location of the metastases [55]. Not only patients with visceral metastases but also those without visceral involvement exhibited a significant benefit from the combination of everolimus plus exemestan. Furthermore, first-line patients in an advanced situation experienced a significant benefit with regard to the mean PFS of 15.01 months in the everolimus plus exemestan group vs. 6.80 months in the placebo plus exemestan group (HR 0.38) [55].

\section{PD-0332991 increases the efficacy of letrozole}

A further substance that specifically acts on a signalling pathway is palbociclib, that was still designated PD-0332991 in the presentation of the first randomised phase II trial. This substance is a selective inhibitor of CDK 4/6 and significantly hinders cell cycle progression. In a randomised phase II trial letrozole alone was compared with letrozole + PD-0332991 [56]. The primary endpoint was the progression-free survival (PFS). For $n=165$ patients a marked, statistically significant improvement of mean PFS (26.1 vs. 7.5 months) with a hazard ratio of 0.37 (95\% CI
Therapie $(n=189)$ oder endokriner Therapie + Bevacizumab $(15 \mathrm{mg} /$ $\mathrm{kg} ; \mathrm{n}=191$ ) randomisiert. Primärer Endpunkt war erneut das progressionsfreie Überleben (PFS), das mit der Kombination von Bevacizumab plus endokrine Therapie numerisch, aber nicht signifikant verbessert wurde ( 18,4 vs. 13,8 Monate, HR 0,83, 95\%-KI 0,65-1,06; $\mathrm{p}=0,14)$. Dem gegenüber stand eine deutliche Erhöhung hämatologischer und auch nicht hämatologischer Nebenwirkungen.

\section{Mehr Daten zu Eribulin}

In einer randomisierten Phase-III-Studie $(\mathrm{n}=1102)$ wurde Eribulin bei Patientinnen mit metastasiertem Mammakarzinom auch in früheren als bisher zugelassenen Therapielinien mit Capecitabin verglichen [75]. Primäre Endpunkte waren Gesamtüberleben (OS) und progressionsfreies Überleben (PFS). In der Gesamtpopulation zeigte sich unter Eribulin ein numerischer Trend zugunsten einer Verbesserung des OS (15,9 vs. 14,5 Monate; $p=0,056)$. Das PFS wurde gegenüber Capecitabin nicht verlängert ( 4,1 vs. 4,2 Monate; $p=0,305$ ). In einer explorativen Subgruppenanalyse zeigte sich, dass Patientinnen mit HER2/neu-negativen Tumoren $(n=755)$ einen Nutzen haben könnten. Bei ihnen verlängerte Eribulin das Gesamtüberleben von 13,5 auf 15,9 Monate $(H R=0,838)$. Bei triple-negativen Tumoren wurde in einer ungeplanten Analyse das OS sogar von 9,4 auf 14,4 Monate verlängert $(\mathrm{HR}=0,70)$.

\section{Update der CONFIRM-Studie:}

\section{Fulvestrant $500 \mathrm{mg}$ vs. Fulvestrant $250 \mathrm{mg}$}

Auf dem SABCS 2012 wurde die Follow-up-Analyse der CONFIRMStudie nach 75\% Todesfällen vorgestellt [53]. Die mittlere Gesamtüberlebenszeit betrug 26,4 Monate für Fulvestrant $500 \mathrm{mg}$ und 22,3 Monate für Fulvestrant $250 \mathrm{mg}$ (HR=0,81, 95\%-KI 0,69-0,96; $\mathrm{p}=0,016$ ). Dieser Vorteil war nicht mit erhöhter Toxizität verbunden; insgesamt gab es keine klinisch relevanten Unterschiede in den Sicherheitsprofilen zwischen den beiden Behandlungsgruppen. Letztlich bestätigen diese Ergebnisse die bereits schon aus frühen Fulvestrant-Studien bekannte positive Dosis-Wirkungs-Beziehung von Fulvestrant.

\section{BOLERO-2 Studie: signifikante Verlängerung}

\section{des medianen PFS in allen Subgruppen}

Im Januar 2012 ist die erste Analyse der BOLERO-2-Studie voll publiziert worden [54]. Die Hinzugabe von Everolimus zu einer Therapie mit Exemestan hat eine deutliche Verbesserung des progressionfreien Überlebens gezeigt. Die finale Analyse der Phase-III-Studie BOLERO-2 zeigte ein medianes progressionsfreies Überleben (PFS) von 11 Monaten unter der Behandlung mit Everolimus in Kombination mit Exemestan für postmenopausale Patientinnen mit fortgeschrittenem hormonrezeptorpositivem, HER2-negativem Mammakarzinom [55]. Auf dem SABCS 2012 wurden die Daten der vordefinierten Subgruppen in der zentralen Auswertung vorgestellt. Alle Patientinnen profitieren signifikant bezüglich des medianen PFS von der Therapie mit Everolimus plus Exemestan (HR $=0,45$; 95\%-KI: 0,38-0,54; $\mathrm{p}<0,0001$ ) - unabhängig von Alter, Anzahl der Vortherapien sowie Ort der Metastasierung [55]. Sowohl Patientinnen mit viszeralen Metastasen als auch Patientinnen ohne viszerale Beteiligung zeigten einen signifikanten Nutzen von der Kombination Everolimus plus Exemestan. Auch Erstlinienpatientinnen in der fortgeschrittenen Situation erzielten einen signifikanten Vorteil bezüglich des medianen PFS von 15,01 Monaten in der Everolimus-plus-Exemestan-Gruppe vs. 6,80 Monaten in der Placebo-plus-Exemestan-Gruppe $(\mathrm{HR}=0,38)$ [55]. 


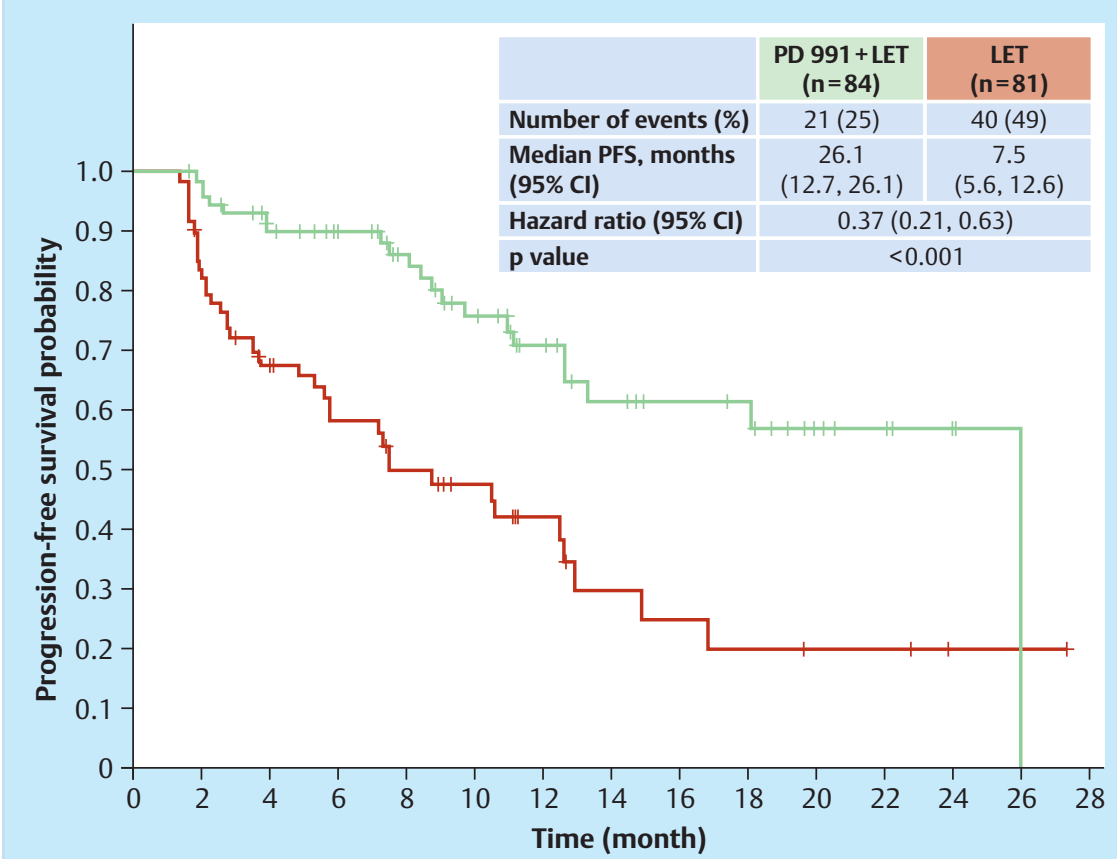

Fig. 3 Improvement of the progression-free survival through the addition of PD-0332991 to a letrozole therapy in a phase II trial (after [56]).

0.21-0.63; p < 0.001, - Fig. 3) was observed. The most frequently reported adverse events due to the treatment in the combination arm were neutropenia, leukopenia, anaemia and fatigue. Interestingly, the strongest predictor for efficacy was the hormone receptor positive status. The efficacy needs to be confirmed in a large international phase II trial (A5481008/TRIO022).

\section{Individualised medicine}

Biomarker analysis in the framework

of the CLEOPATRA trial

As already mentioned, it could be demonstrated within the framework of the CLEOPATRA trial that the antibody pertuzumab in combination with trastuzumab in the first-line therapy for metastatic breast cancer effected a significant prolongation of progression-free survival of over 6 months [57]. In the course of this trial an additional biomarker programme was undertaken in order to identify potential new predictive markers. None of the investigated biomarkers such as EGFR, HER3, IGF1R, PTEN, pAKT, AREG, betacellulin as well as c-myc, PI3CA, FCyR-polymorphisms or serum HER2, TGF- $\alpha$ or, respectively, EGF were suitable to predict a response to an HER2 targeted therapy [58]. Thus HER2 remains at present as the only suitable predictive marker for HER2 targeted therapy.

\section{HER2 status of circulating tumour cells} in the framework of the SUCCESS-C trial

The presence of circulating and disseminated tumour cells has become established in the past few years as a prognostic factor for breast cancer [59]. The sole determination of the presence of tumour cells is undergoing further development and, at present, attempts are being made to determine the molecular characteristics of the disseminated tumour cells and render them useful for clinical practice. Thus, for example, HER2-negative patients can, in the course of tumour progression, develop HER2-positive metastases. For this reason the HER2 status of the circulating tumour cells (CTC) as a potential starting point for later metastasis was investigated in the SUCESS-C trial, for which an inclusion cri-

\section{PD-0332991 erhöht Effektivität von Letrozol}

Eine weitere Substanz, die gezielt in einen Signalweg eingreift, ist das Palbociclib, welches bei der Vorstellung der ersten randomisierten Phase-II-Studie noch PD-0332991 genannt wurde. Die Substanz ist ein selektiver Inhibitor von CDK 4/6 und verhindert maßgeblich die Zellzyklusprogression. In einer randomisierten Phase-II-Studie wurde Letrozol alleine gegenüber Letrozol + PD-0332991 verglichen [56]. Primärer Endpunkt war das progressionsfreie Überleben (PFS). Für $\mathrm{n}=165$ Patientinnen zeigte sich eine deutliche, statistisch signifikante Verbesserung des medianen PFS (26,1 vs. 7,5 Monate) mit einer Hazard Ratio von 0,37 (95\%-KI 0,21-0,63; p<0,001, @ Abb. 3). Die am häufigsten berichteten, behandlungsbedingten Adverse Events im Kombinationsarm waren Neutropenie, Leukopenie, Anämie und Fatigue. Interessanterweise war der stärkste Prädiktor für eine Wirksamkeit die Hormonrezeptorpositivität. Nun soll in einer großen, internationalen Phase-III-Studie (A5481008/TRIO022) die Wirksamkeit bestätigt werden.

\section{Individualisierte Medizin}

\section{Biomarkeranalyse im Rahmen der CLEOPATRA-Studie}

Wie bereits erwähnt, konnte im Rahmen der CLEOPATRA-Studie konnte gezeigt werden, dass der Antikörper Pertuzumab in Kombination mit Trastuzumab in der First-Line-Therapie des metastasierten Mammakarzinoms eine signifikante Verlängerung des progressionsfreien Überlebens um über 6 Monate erzielt [57]. Im Rahmen dieser Studie wurde zusätzlich ein Biomarkerprogramm aufgelegt, um potenzielle neue prädiktiver Marker zu identifizieren. Keiner der untersuchten Biomarker wie EGFR, HER3, IGF1R, PTEN, pAKT, AREG, betacellulin sowie c-myc, PI3CA, FCyR-Polymorphismen oder Serum HER2, TGF- $\alpha$ bzw. EGF waren geeignet, um das Ansprechen auf eine HER2-zielgerichtete Therapie vorherzusagen [58]. Somit bleibt HER2 derzeit der einzige geeignete prädiktive Marker für eine HER2-zielgerichtete Therapie. 


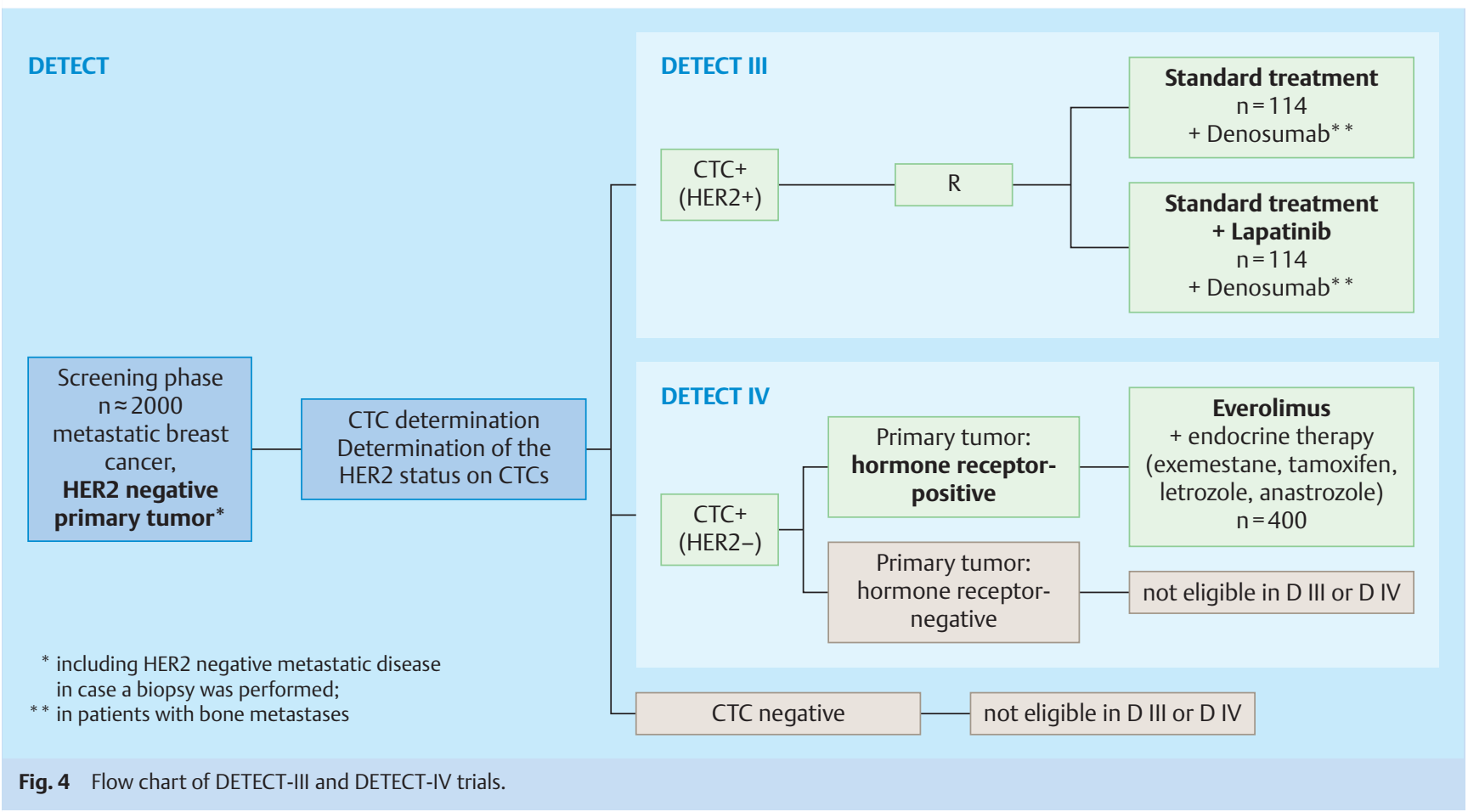

terion was the HER2-negative nature of the primary tumour [60]. In total $6.9 \%$ of the patients exhibited CTC. 50 of 136 (36.8\%) patients had HER2-positive CTC in spite of an HER2-negative primary tumour. In the case of a prognostic relevance of these cells, the question must be posed as to whether these patients could possibly benefit from an HER2-targeted therapy.

The currently on-going DETECT-III and DETECT-IV trials ( $\bullet$ Fig. 4) are addressing this question by means of a therapeutic intervention on the basis of the CTC status in metastatic situations.

\section{Relevance of $\mathrm{BCl}$, Oncotype $\mathrm{DX}^{\circledR}$ and IHC4}

for the prediction of late recurrences in cases of hormone receptor-positive breast cancer

Sgroi et al. compared the potential of various multi-gene assays such as Oncotype $\mathrm{DX}^{\circledR}, \mathrm{IHC} 4$ and breast cancer index (BCI), a combination of HOXb13 and IL17BR as well as the molecular grade index for the prediction of early and late recurrences (after 5 years) in the TRANS-ATAC collective (HR-positive primary breast cancer patients under adjuvant endocrine therapy) [61]. With all three assays patients with an elevated risk for an early recurrence ( $0-5$ years) were identified. However, the BCI was the only prognostic marker for ther prediction of late recurrences (5-10 years after the first diagnosis).

\section{The prognostic relevance of Endopredict}

in the prediction of late recurrences

The relevance of Endopredict for the prediction of late recurrences was investigated by Dubsky et al. [62]. For this purpose tissue samples from patients of the ABCSG-6 trial (tamoxifen arm only) or the ABCSG-8 trial (tamoxifen or switch therapy) were examined with the Endopredict assay. $49 \%$ of the patients were placed in a low-risk group by Endopredict. The survival analysis showed that patients with a lower score have a significantly lower risk for not only early but also for late recurrences. In a multivariate analysis the Endopredict score was the strongest inde-
HER2-Status zirkulierender Tumorzellen

im Rahmen der SUCCESS-C-Studie

Das Vorhandensein von zirkulierenden und disseminierten Tumorzellen hat sich in den vergangenen Jahren als Prognosefaktor beim Mammakarzinom etabliert [59]. Die alleinige Bestimmung der Präsenz von Tumorzellen wurde jedoch weiterentwickelt, und momentan wird versucht, die molekularen Charakteristika der disseminierten Tumorzellen zu bestimmen und für die klinische Praxis nutzbar zu machen. So können z.B. HER2-negative Patientinnen im Rahmen der Tumorprogression HER2-positive Metastasen entwickeln. Aus diesem Grund wurde in der SUCESS-C-Studie, deren Einschlusskriterium HER2-Negativität des Primärtumors war, der HER2-Status der zirkulierenden Tumorzellen (CTC) als potenzieller Ausgangspunkt einer späteren Metastasierung untersucht [60]. Insgesamt wiesen 6,9\% der Patientinnen CTC auf. 50 von 136 (36,8\%) Patientinnen hatten trotz HER2-negativem Primärtumor HER2-positive CTC. Im Falle einer prognostischen Relevanz dieser Zellen muss die Frage gestellt werden, ob diese Patientinnen möglicherweise von einer HER2-zielgerichteten Therapie profitieren.

Die derzeit laufenden DETECT-III- und DETECT-IV-Studien ( $\bullet$ Abb. 4) widmen sich durch eine Therapieintervention auf der Grundlage des CTC-Status in der metastasierten Situation dieser Frage.

\section{Bedeutung von $\mathrm{BCl}$, Oncotype $\mathrm{DX}{ }^{\circledR}$ und $\mathrm{IHC} 4$}

für die Vorhersage von Spätrezidiven

beim hormonrezeptorpositiven Mammakarzinom

Sgroi et al. verglichen das Potenzial von verschiedenen Multigene-Assays wie Oncotype DX ${ }^{\circledR}$, IHC4 und Breast Cancer Index $(\mathrm{BCI})$, eine Kombination aus HOXb13 und IL17BR sowie Molecular Grade Index, zur Vorhersage von Früh- und Spätrezidiven (nach 5 Jahren) im TRANS-ATAC-Kollektiv (HR-positive primäre Mammakarzinompatientinnen mit adjuvanter endokriner Therapie) [61]. Mit allen 3 Assays konnten Patientinnen mit einem erhöhten Risiko für ein Frührezidiv (0-5 Jahre) identifiziert werden. Allerdings war der BCI-Index 
pendent prognostic marker for late recurrences. Interestingly, the proliferative gene set of the assays was associated above all with an increased risk for early recurrence, while the genes that belong to the oestrogen receptor signal transduction pathway are mainly associated with an elevated risk for late recurrence.

\section{Ki-67 as therapy-resistance marker}

\section{in neoadjuvant chemotherapy}

Ki-67 plays an important role in the classification of luminal breast cancer. At present the cut-off level is $14 \%$ in order to distinguish between luminal A and B types [63]. However, the cutoff level for Ki-67 has repeatedly been a topic of discussion. It may also be possible that different cut-off levels are valid for different clinical scenarios (patients with or without chemotherapy) [64].

It has already been shown in clinical cohorts that the Ki-67 determination in punch biopsies can predict a therapy response, especially among patients with triple-negative and hormone receptor-positive breast cancer [27]. Similar analyses are now being performed in the prospective GeparTrio study of tumour material from 1101 patients [65]. In the analysis both the prognostic and the predictive relevance with regard to a pathological complete remission ( $\mathrm{pCR}$ ) were confirmed. This was valid, however, for 93 of 94 investigated cut points, thus the authors concluded that Ki67 is a continuous variable that can only be defined for one arbitrary cut point. For the practice, the working group suggested the following 3 groups with prognostic and predictive relevance: $<15 \%$ vs. $15-35 \%$ vs. $>35 \%$.

\section{Health economics and health-care research}

Individualised therapy that currently determines both research as well as clinical routine is particularly relevant with regard to health economics since, on the one hand, through targeted use it increases efficacy and thus reduces follow-on costs by avoiding recurrences and metastatic courses while, on the other hand, it saves monetary resources by a reduction of over treatment. Accordingly, test systems that support the decision making for or against a therapy will be especially relevant in the future. Procedures such as Oncotype DX ${ }^{\circledR}$, Endopredict ${ }^{\circledR}$, or Femtelle ${ }^{\circledR}$ have a large potential whereby prospective trial results still need to awaited for the first mentioned. For Oncotype DX ${ }^{\circledR}$ the results of cost-effectiveness analyses from numerous countries are available. At the SABCS 2012 a model from Japan was presented [66]. Here the costs for the test were compared with the thereby gained QALYs (quality-adjusted life years) and the costs saved for therapies not performed. The calculated costs amounted to 8023 \$ per QALY gained (in the American health-care system all therapies with costs $<50000 \$$ per QALY gained are considered to be cost-effective). The cost of the test and the age of the patient had the greatest influence on the model. When the lower recurrence rates in Japan compared to those in USA and England are used, the costs amount to 14225 \$ per QALY - and thus remaining cost effective. This emphasises, however, the necessity for each country to use its own model. In a recently published article these costs were also calculated for Germany [67]. A gain of 0.06 QALYs per patient with a saving in costs of $561 €$ were calculated - an absolutely dominating option (gain in life as well as saving in costs). Thus, from the health economics point of view, this will become an important process as soon as these data are confirmed in prospective studies.

The determination of UPA and PAI-1 can help to avoid chemotherapy for patients with a medium-risk primary breast cancer. der einzige prognostische Marker für die Vorhersage von Spätrezidiven (5-10 Jahre nach Erstdiagnose).

\section{Die prognostische Bedeutung von Endopredict}

\section{in der Vorhersage von Spätrezidiven}

Die Bedeutung von Endopredict zur Vorhersage von Spätrezidiven wurde von Dubsky et al. untersucht [62]. Hierzu wurden Gewebeproben von Patientinnen aus der ABCSG-6-Studie (nur Tamoxifen-Arm) oder ABCSG-8 Studie (Tamoxifen oder Switch-Therapie) mit dem Endopredict-Assay untersucht. 49\% der Patientinnen wurden in eine Low-Risk-Gruppe mit Endopredict eingestuft. Die Überlebensanalysen zeigten, dass Patientinnen mit einem niedrigeren Score sowohl ein signifikant geringeres Risiko für Früh-, aber auch für Spätrezidive hatten. Der Endopredict-Score war in der multivariaten Analyse der stärkste unabhängige prognostische Marker für Spätrezidive. Interessanterweise war das proliferative Genset des Assays vor allem mit einem erhöhten Risiko für Frührezidive assoziiert, während die Gene, die zu dem Östrogenrezeptor-Signaltransduktionsweg zugehörig sind, vor allem mit einem erhöhtem Risiko für Spätrezidive assoziiert waren.

\section{Ki-67 als Therapieresistenzmarker}

in der neoadjuvanten Chemotherapie

Ki-67 spielt bei der Einteilung der luminalen Mammakarzinome eine wichtige Rolle. Derzeit liegt der Cut-off-Level bei $14 \%$, um zwischen Luminal A und B zu unterscheiden [63]. Dennoch wird der Cut-offLevel für Ki-67 immer wieder infrage gestellt. Es könnte auch sein, dass für unterschiedliche klinische Szenarien (Patientinnen mit oder ohne Chemotherapie) unterschiedliche Cut-offs gelten [64].

Bereits an Klinikkohorten konnte gezeigt werden, dass die Ki-67-Bestimmung in der Stanze ein Therapieansprechen insbesondere bei Patientinnen mit einem triple-negativen und hormonrezeptorpositiven Mammakarzinom vorhersagen kann [27]. Ähnliche Analysen wurden nun in der prospektiven GeparTrio-Studie an Tumormaterial von 1101 Patientinnen durchgeführt [65]. In der Analyse konnte die prognostische und prädiktive Relevanz in Bezug auf eine pathologische Komplettremission (pCR) bestätigt werden. Dies galt allerdings für 93 von 94 untersuchte Cut-Points, sodass die Schlussfolgerung der Autoren war, dass es sich bei Ki-67 um eine kontinuierliche Variable handelt, für die nur ein arbiträrer Cut-Point definiert werden kann. Für die Praxis schlug die Arbeitsgruppe folgende 3 Gruppen mit prognostische und prädiktive Relevanz vor: < $15 \%$ vs. $15-35 \%$ vs. $>35 \%$.

\section{Gesundheitsökonomie und Versorgungsforschung}

Die individualisierte Therapie, die derzeit sowohl Forschung als auch den klinischen Alltag bestimmt, ist für die Gesundheitsökonomie besonders relevant, da sie einerseits durch den gezielteren Einsatz die Effektivität erhöht und somit Folgekosten durch die Vermeidung von Rezidiven und metastasierten Verläufe senkt, andererseits durch die Reduktion von Übertherapien monetäre Ressourcen schont. Dementsprechend sind Testsysteme, welche die Entscheidung für oder gegen eine Therapie unterstützen, zukünftig besonders relevant. Ein großes Potenzial haben hier Verfahren wie Oncotype DX ${ }^{\circledR}$, Endopredict ${ }^{\circledR}$, oder Femtelle ${ }^{\circledR}$, wobei für erstere noch prospektive Studienergebnisse abgewartet werden sollten. Für Oncotype DX ${ }^{\circledR}$ liegen Ergebnisse von Kosten-Effektivitäts-Analysen aus zahlreichen Ländern vor. Beim SABCS 2012 wurde ein Modell aus Japan vorgestellt [66]. Hierbei wurden die Kosten des Tests gegenüber den gewonnenen QALYs (qualitätsadjustierte Lebensjahre) und den Kosten für die eingesparten Therapien verglichen. Die kalkulierten Kosten lagen bei $8023 \$$ pro gewonnenem QALY (im amerikanischen Gesundheitswesen wer- 
Table 1 Average ICER (costs for an additional QALY) in \$ [69]; GIST: gastrointestinal stromal tumour; HCC: hepatocellular carcinoma; NSCLC: non-small cell lung cancer; pNET: primitive neuroectodermal tumour).

\begin{tabular}{|lllllllllll} 
& Breast & Colon & Stomach & GIST & HCC & Head/neck & NSCLC & Ovary & Kidney & PNET \\
Bevacizumab & 248149 & 100825 & - & - & - & - & 197787 & 479712 & - & - \\
\hline Cetuximab & - & 77433 & - & - & - & 34593 & 492828 & - & - \\
\hline Erlotinib & - & - & - & - & - & - & - & - \\
\hline Everolimus & - & - & - & - & - & - & - & - & 75582 & - \\
\hline Imatinib & - & - & - & 33275 & - & - & - & - & - & - \\
\hline Lapatinib & 86852 & - & - & - & - & - & - & - & - \\
\hline Sorafenib & - & - & - & - & 42456 & - & - & - & - \\
\hline Sunitinib & - & - & - & 74496 & - & - & - & - & - \\
\hline Trastuzumab & 32441 & - & 19720 & - & - & - & - & - & - & - \\
\hline
\end{tabular}

In a prospective, multicentre trial, the use of the test in 93 patients helped to avoid 35 therapies or, respectively, for 210 cycles 12.1 years of chemotherapy application time [68]. In addition, costs of $221816 €$ for systemic therapy, $25749 €$ for GCS-F, and $34353 \$$ for further accompanying therapies were saved (in total $281918 \$$ ). With test costs of $350 \$$ per patient the return of investment ratio amounted to 8.4 : 1 . Further costs (e.g., for side effects) were not taken into consideration but would clearly increase the ratio in favour of the test.

For individualised therapy, targeted therapeutic agents are also particularly relevant - however these are associated with enormous costs. A presented metaanalysis (1576 screened and 60 evaluated publications) has now compared the cost-effectiveness ratios of the available antibodies and tyrosine kinase inhibitors for various solid tumours [69]. In comparison to other therapies, trastuzumab was significantly the most cost-effective therapy option (32000\$ vs. 108000 \$ per QALY, p<0.001) ( Table 1). $84 \%$ of the trastuzumab studies showed an incremental cost efficacy ratio (ICER) $<40000 \$$ (vs. $32 \%$ for the other studies). In the adjuvant situation in particular, the cost efficacy was especially high ( 18000 \$ vs. 29000 \$ per QALY).

For the use of everolimus in patients with a hormone receptorpositive breast cancer in the first or second line after failure of letrozole and anastrozole, a separate report was presented [70]. In the course of a 1-year budget impact analysis, the cost burden after approval for the American health-care system was calculated. The improvement of PFS (based on the BOLERO-2 trial), the drug costs and the medical counselling costs as well as compliance were taken into account. For the combination of exemestan and everolimus, costs of $64572.56 \$$ per year and patient were calculated. Although these costs appear at first to be high and increase the drug budget, the medical budget is concomitantly reduced due to the avoidance of costs for progression. Thus, the analysis shows that a lower burden may be assumed for the cost bearer.

\section{Evaluation by Expert Committees}

$\nabla$

In light of the enormous amount of data presented at congresses and published in the literature each year, expert committees that view the material as a whole and then draw conclusions for the practice are most certainly useful and worthwhile. This takes place in Germany, e.g., in the form of recommendations of the AGO and the S3 guidelines. In the international scene the St. Gallen consensus conference on the treatment of primary breast cancer is the established organ. It consisted this year den alle Therapien mit Kosten $<50000 \$$ pro gewonnenem QALY als kosteneffektiv angesehen). Größte Einflüsse auf das Modell hatten die Kosten des Tests und das Alter der Patientin. Wenn die in Japan im Vergleich zu den USA und England geringeren Rezidivraten verwendet werden, entstehen Kosten von 14225 \$ pro QALY - somit weiterhin kosteneffektiv. Dieses unterstreicht jedoch auch die Notwendigkeit, dass für jedes Land ein eigenes Modell erforderlich ist. In einer kürzlich publizierten Arbeit wurde dieses auch für Deutschland berechnet [67]. Es wurde ein Zugewinn von 0,06 QALYs pro Patientin bei einer Kostenersparnis von $561 €$ kalkuliert - eine absolut dominante Option (Zugewinn an Leben als auch kosteneinsparend). Somit handelt es sich hier aus gesundheitsökonomischer Sicht um ein bedeutsames Verfahren, sobald dieses durch Daten aus prospektiven Studien bestätigt wird.

Die Bestimmung von uPA und PAI-1 kann helfen, Chemotherapien bei Patientinnen mit einem primären Mammakarzinom mittleren Risikos vermeiden. In einer prospektiven, multizentrischen Studie konnten durch den Einsatz des Tests bei 93 Patientinnen 35 Therapien bzw. bei 210 Zyklen 12,1 Jahre Chemotherapieapplikationszeit vermieden werden [68]. Es wurden zudem Kosten von $221816 €$ für Systemtherapien, $25749 €$ für GCS-F, und 34353 \$ für weitere Begleittherapien eingespart (gesamt 281918 \$). Bei Testkosten von 350 \$ pro Patientin lag die Return-of-Investment-Ratio bei $8,4: 1$. Weitere Kosten (z.B. für Nebenwirkungen) wurden nicht berücksichtigt und würden die Ratio weiter deutlich zugunsten des Test erhöhen.

Für die individualisierten Therapien sind die zielgerichteten Therapeutika besonders relevant - diese sind jedoch mit massiven Kosten verbunden. Eine vorgestellte Metaanalyse (1576 gescreente und 60 berücksichtigte Publikationen) hat nun die Kosteneffektivität der verfügbaren Antikörper und Tyrosinkinasehemmer bei den verschiedenen soliden Tumoren verglichen [69]. Im Vergleich zu weiteren Therapien war Trastuzumab die signifikant kosteneffektivste Therapieoption (32000\$ vs. 108000 \$ pro QALY, p<0,001) (๑ Tab. 1). 84\% der Trastuzumab-Studien zeigten eine inkrementelle Kosteneffektivitätsratio (ICER) < 40000 (vs. 32\% der weiteren Studien). Insbesondere in der adjuvanten Situation war die Kosteneffektivität besonders hoch (18000 \$ vs. 29000 \$ pro QALY).

Für den Einsatz von Everolimus bei Patientinnen mit einem hormonrezeptorpositiven Mammakarzinom in der First oder Second Line nach Versagen von Letrozol und Anastrozol wurde eine separate $\mathrm{Ar}$ beit vorgestellt [70]. Im Rahmen einer 1-Jahres-Budget-Impact-Analyse wurde kalkuliert, welche Kostenbelastung für das amerikanische Gesundheitswesen nach der Zulassung entsteht. Es wurden die Verbesserung des PFS (basierend auf der BOLERO-2-Studie), die Medikamentenkosten und die medizinischen Betreuungskosten als auch die Compliance berücksichtigt. Für die Kombination von Exemestan und Everolimus wurden 64572,56 \$ pro Jahr und Patientin berechnet. Ob- 
(2013) of 50 experts from a total of 19 countries. They discuss clinically relevant topics and attempt to form a majority opinion as far as the differing basic conditions in the different countries allow.

One of the trials that had an influence on the voting of the St. Gallen expert committee was the START trial (see above) [20]. A hypofractionated irradiation with, e.g., $40 \mathrm{~Gy}$ in 15 sessions as standard therapy for all patients after breast-preserving operations received $59.2 \%$ of the votes of the panel members. A different formulation (hypofractionated radiotherapy as standard therapy for "selected patients"), on the other hand, received over $72 \%$ of the member's votes. For further recommendations on the local therapy for breast cancer, we explicitly refer to the currently valid AGO recommendations and the $\mathrm{S} 3$ guidelines as well as the comprehensive reports of the St Gallen committee members that will appear in the future.

Since the classification of breast cancer patients into the molecular subtypes (triple-negative/luminal A like/luminal B like/HER2positive) is continuously gaining in clinical relevance, the St. Gallen expert committee has also addressed this topic. The molecular subtype may be approximated by the following factors: hormone receptor expression, HER2 status, grading and the proliferation, determined by Ki-67 expression. Further genes, the determination of which is offered in some multi-gene assays (e.g., OncotypeDX ${ }^{\circledR}$, Mammaprint, and Endopredict) are not yet considered to be necessary for clinical routine. A majority of the committee considers the performance of immunohistochemistry for Ki-67 to be necessary to distinguish between luminal-A-like and luminal-B-like tumours. A distinction on the basis of grading is considered to be not sufficiently substantiated for clinical practice. The report of Cheang et al. proposes a biological cut-off value of $14 \%$ [63], but this does not mean that this is also the best predictor for, e.g., a response to chemotherapy $[27,65]$, which in retrospective clinical analyses lies at about $35 \%$. It is unclear whether the majority of committee members decided for a cutoff value of $20 \%$ for just this reason.

In regard to the determination of an HER2 positive status, the recommendations of the ASCO/CAP (American Society of Clinical Oncology/College of American Pathologists) [71] have in general been confirmed by the St. Gallen group, although these recommendations are still under discussion with regard to the cut-off value for a FISH test and the utility of immunohistochemistry [72].

It is clear that in a time when multi-gene expression tests are available commercially but have not yet been validated in prospective studies that the expert committee in St. Gallen has concerned itself in detail with the clinical utility of these tests (e.g., OncotypeDX ${ }^{\circledR}$, Mammaprint, Endopredict, and PAM50).

In general, the use of these tests in addition to the above-mentioned markers (ER, PR, grading, Ki-67 and HER2) is considered by most committee members not to be necessary. Certain special clinical situations are exceptions in which an indication for chemotherapy is not already given by a certain biomarker, e.g., for a hormone receptor-positive, HER2-negative breast cancer. In such a case more than half of the committee members felt that a multi-gene test could be useful in the decision making for or against chemotherapy.

With regard to current therapy recommendations, we refer to the short version of the of the S3 guidelines included in this issue [76] and the actual AGO recommendations [73]. wohl diese Kosten zunächst hoch erscheinen, und das Medikamentenbudget ansteigt, reduziert sich jedoch das medizinische Budget durch die Vermeidung von Kosten nach Progression. Somit zeigt die Analyse, dass nur von einer geringen Belastung für den Kostenträger auszugehen ist.

\section{Bewertung durch Expertengremien \\ $\nabla$}

Bei der Fülle an Daten, welche jedes Jahr auf Kongressen und in Fachzeitschriften veröffentlicht werden, sind Expertengremien, welche die Arbeiten in der Zusammenschau bewerten und daraus Schlussfolgerungen für die Praxis ziehen, durchaus hilfreich und sinnvoll. Dies geschieht z. B. in Deutschland im Rahmen der Empfehlungen der AGO und der S3-Leitlinien. International hat sich hier die St.-Gallen-Konsensuskonferenz zur Behandlung des primären Mammakarzinoms etabliert. Sie bestand dieses Jahr (2013) aus 50 Experten aus insgesamt 19 Ländern. Diese stimmen über klinisch relevante Fragestellungen ab und versuchen, ein Mehrheitsvotum zu bilden, soweit dies bei den unterschiedlichen Grundbedingungen in den verschiedenen Ländern möglich ist.

Eine der Studien, die einen Einfluss auf eine Abstimmung in dem St.-Gallen-Expertengremium hatte, war die START-Studie (siehe oben) [20]. Einer hypofraktionierten Bestrahlung mit z.B. $40 \mathrm{~Gy}$ in 15 als Standardtherapie für alle Patientinnen nach einer brusterhaltenden Operation stimmten 59,2\% der Panelmitglieder zu. In einer anderen Formulierung (hypofraktionierte Strahlentherapie als Standardtherapie für „ausgewählte Patientinnen“) hingegen stimmten über 72\% aller Mitglieder zu. Für weitere Empfehlungen zur lokalen Therapie des Mammakarzinoms verweisen wir ausdrücklich auf die geltenden AGO-Empfehlungen und S3-Leitlinien sowie auf den in Zukunft erscheinenden ausführlichen Kongressbericht der St.-GallenPanelmitglieder.

Da die Zuordnung der Brustkrebspatientinnen in die molekularen Subtypen (triple-negativ/luminal A like/luminal B like/HER2-positiv) immer mehr an klinischer Bedeutung gewinnt, hat sich auch das St.-Gallen-Expertengremium mit dieser Fragestellung beschäftigt. Der molekulare Subtyp lässt sich mit den folgenden Faktoren annähern: Hormonrezeptorexpression, HER2-Status, Grading und der Proliferation, bestimmt durch die Ki-67-Expression. Mehr Gene, deren Bestimmung in einigen Multigen-Assays (z.B. OncotypeDX ${ }^{\circledR}$, Mammaprint, Endopredict) angeboten wird, wurden momentan vom Gremium für den klinischen Alltag als noch nicht erforderlich befunden. Eine Mehrheit des Gremiums hielt die Durchführung einer Immunhistochemie für Ki-67 für notwendig, um zwischen LuminalA-like- und Luminal-B-like-Tumoren zu unterscheiden. Eine Unterscheidung anhand des Gradings wurde für die klinische Praxis als nicht ausreichend bewertet. Die Arbeit von Cheang et al. gibt einen biologischen Cut-off-Wert von 14\% an [63], was nicht bedeutet, dass dies auch der beste Prädiktor z. B. für das Ansprechen einer Chemotherapie ist [27,65], der in retrospektiven klinischen Analysen bei ungefähr 35\% liegt. Unklar ist, ob sich die Panelmitglieder deswegen mehrheitlich für einen Cut-off von $20 \%$ entschieden haben.

In Bezug auf die Bestimmung für eine HER2-Positivität wurde in St. Gallen im Allgemeinen die Empfehlungen der ASCO/CAP bestätigt (American Society of Clinical Oncology/College of American Pathologists) [71], obwohl diese Empfehlungen sowohl in Bezug auf den Cutoff-Wert für eine positive FISH-Testung und den Stellenwert einer Immunhistochemie aktuell diskutiert werden [72].

Es ist klar, dass in einer Zeit, in der Multigen-Expressionsanalyse bereits auf dem Markt erhältlich sind, aber noch nicht in prospektiven Studien validiert sind, sich das Expertengremium in St. Gallen aus- 


\section{Conflict of Interest}

This work was undertaken as the result of a roundtable discussion sponsored by the Novartis Company in Germany. Novartis did not participate in any way in the preparation of this manuscript. The authors alone are responsible for the contents.

\section{Affiliations}

${ }^{1}$ Department of Gynecology and Obstetrics, University Hospital Erlangen, Friedrich-Alexander University Erlangen-Nuremberg, Erlangen

2 Department of Gynecology and Obstetrics, University Hospital Aachen, Aachen

3 Frauenklinik, Universitätsklinikum Heidelberg, Heidelberg

${ }^{4}$ Klinik für Senologie, Kliniken Essen Mitte, Essen

${ }^{5}$ Department of Gynecology and Obstetrics, University Hospital Düsseldorf, Heinrich Heine Universität Düsseldorf, Düsseldorf

${ }^{6}$ Frauenklinik, Klinikum der Universität Ulm, Ulm

7 Klinik für Gynäkologie und Geburtshilfe, Marienhospital Bottrop, Bottrop

${ }^{8}$ Medizinische Klinik und Poliklinik II, Campus Charité Mitte, Berlin

\section{References}

1 Fasching PA, Ekici AB, Adamietz BR et al. Breast cancer risk - genes, environment and clinics. Geburtsh Frauenheilk 2011; 71: 1056-1066

2 Rauh C, Hack CC, Haberle L et al. Percent mammographic density and dense area as risk factors for breast cancer. Geburtsh Frauenheilk 2012; 72: 727-733

3 Vachon CM, Scott CG, Fasching PA et al. Common breast cancer susceptibility variants in LSP1 and RAD51L1 are associated with mammographic density measures that predict breast cancer risk. Cancer Epidemiol Biomarkers Prev 2012; 21: 1156-1166

4 Heusinger K, Loehberg CR, Haeberle L et al. Mammographic density as a risk factor for breast cancer in a German case-control study. Eur J Cancer Prev 2011; 20: 1-8

5 Garcia-Closas M, Couch FJ, Lindstrom S et al. Genome-wide association studies identify four ER negative-specific breast cancer risk loci. Nat Genet 2013; 45: 392-398

6 Bojesen SE, Pooley KA, Johnatty SE et al. Multiple independent variants at the TERT locus are associated with telomere length and risks of breast and ovarian cancer. Nat Genet 2013; 45: 371-384

7 Michailidou K, Hall P, Gonzalez-Neira A et al. Large-scale genotyping identifies 41 new loci associated with breast cancer risk. Nat Genet 2013; 45: 353-361

8 Nickels S, Truong T, Hein R et al. Evidence of gene-environment interactions between common breast cancer susceptibility loci and established environmental risk factors. PLoS Genetics 2013; 9: e1003284

9 Gaudet MM, Kuchenbaecker KB, Vijai J et al. Identification of a BRCA2specific modifier locus at 6p24 related to breast cancer risk. PLoS Genetics 2013; 9: e1003173

10 French JD, Ghoussaini M, Edwards SL et al. Functional variants at the $11 \mathrm{q} 13$ risk locus for breast cancer regulate cyclin D1 expression through long-range enhancers. Am J Hum Genet 2013; DOI: 10.1016/ j.ajhg.2013.01.002

11 Antoniou AC, Wang X, Fredericksen ZS et al. A locus on 19p13 modifies risk of breast cancer in BRCA1 mutation carriers and is associated with hormone receptor-negative breast cancer in the general population. Nat Genet 2010; 42: 885-892

12 Antoni S, Sasco AJ, Dos Santos Silva I et al. Is mammographic density differentially associated with breast cancer according to receptor status? A meta-analysis. Breast Cancer Res Treat 2013; 137: 337-347

13 Heusinger K, Jud SM, Haberle L et al. Association of mammographic density with the proliferation marker Ki-67 in a cohort of patients with invasive breast cancer. Breast Cancer Res Treat 2012; 135: 885-892

14 Heusinger K, Jud SM, Haberle L et al. Association of mammographic density with hormone receptors in invasive breast cancers - results from a case-only study. Int J Cancer 2012; DOI: 10.1002/ijc.27515

15 Fasching PA, Pharoah PD, Cox A et al. The role of genetic breast cancer susceptibility variants as prognostic factors. Hum Mol Genet 2012; 21: 3926-3939

16 Fisher B, Anderson S, Bryant J et al. Twenty-year follow-up of a randomized trial comparing total mastectomy, lumpectomy, and lumpectomy plus irradiation for the treatment of invasive breast cancer. $\mathrm{N}$ Engl J Med 2002; 347: 1233-1241 führlich mit der klinischen Wertigkeit dieser Tests (z.B. OncotypeDX ${ }^{\circledR}$, Mammaprint, Endopredict, PAM50) beschäftigt hat.

Generell wurde die Benutzung dieser Tests zusätzlich zu den oben erwähnten Markern (ER, PR, Grading, Ki-67 und HER2) von den meisten Panel-Mitgliedern als nicht notwendig bezeichnet. Eine Ausnahme bildeten spezielle klinische Situation, in denen eine Chemotherapieindikation nicht bereits durch die bestimmten Biomarker feststeht, wie z. B. bei einem hormonrezeptorpositiven, HER2-negativen Mammakarzinom. Hier befand etwas mehr als die Hälfte der Panel-Mitglieder, dass ein Multigentest bei der Entscheidung für oder gegen eine Chemotherapie helfen könnte.

In Bezug auf aktuelle Therapieempfehlungen verweisen wir auf die in dieser Ausgabe veröffentlichte Kurzversion der S3-Leitlinie [76] und die aktuellen AGO-Empfehlungen [73].

\section{Interessenkonflikt}

$\nabla$

Diese Arbeit entstand in Folge einer von der Firma Novartis Deutschland geförderten Diskussionsrunde. Novartis hatte keinen Anteil bei der Verfassung dieses Manuskripts. Für den Inhalt des Manuskripts sind alleine die Autoren verantwortlich.

17 Veronesi U, Cascinelli N, Mariani L et al. Twenty-year follow-up of a randomized study comparing breast-conserving surgery with radical mastectomy for early breast cancer. N Engl J Med 2002; 347: 12271232

18 Giuliano $A E$. Lymphatic mapping and sentinel node biopsy in breast cancer. JAMA 1997; 277: 791-792

19 Bani HA, Fasching PA, Lux MM et al. Lymphedema in breast cancer survivors: assessment and information provision in a specialized breast unit. Patient Educ Couns 2007; 66: 311-318

20 Haviland JS, Agrawal R, Aird E et al. The UK START (Standardisation of Breast Radiotherapy) Trials: 10-year follow-up results. Cancer Res 2012; 72 (24 Suppl.): 100 s

21 Flyger $H$, Massarut S, Alvarado $M$ et al. Targeted intraoperative radiotherapy for early breast cancer: TARGIT-A trial- updated analysis of local recurrence and first analysis of survival. Cancer Res 2012; 72 (24 Suppl.): $100 \mathrm{~s}$

22 Boughey JC, Suman VJ, Mittendorf EA et al. The role of sentinel lymph node surgery in patients presenting with node positive breast cancer (T0-T4, N1-2) who receive neoadjuvant chemotherapy - results from the ACOSOG Z1071 trial. Cancer Res 2012; 72 (24 Suppl.): 94 s

23 Kuehn T, Bauerfeind IGP, Fehm T et al. Sentinel lymph node biopsy before or after neoadjuvant chemotherapy - final results from the prospective German, multiinstitutional SENTINA-trial. Cancer Res 2012; 72 (24 Suppl.): 95s

24 von Minckwitz G, Untch M, Blohmer JU et al. Definition and impact of pathologic complete response on prognosis after neoadjuvant chemotherapy in various intrinsic breast cancer subtypes. J Clin Oncol 2012; DOI: $10.1200 / J C O .2011 .38 .8595$

25 Denkert C, Huober J, Loibl S et al. HER2 and ESR1 mRNA expression levels and response to neoadjuvant trastuzumab plus chemotherapy in patients with primary breast cancer. Breast Cancer Res 2013; 15: R11

26 Witzel I, Loibl S, von Minckwitz G et al. Predictive value of HER2 serum levels in patients treated with lapatinib or trastuzumab - a translational project in the neoadjuvant GeparQuinto trial. Br J Cancer 2012; 107: 956-960

27 Fasching PA, Heusinger K, Haeberle L et al. Ki67, chemotherapy response, and prognosis in breast cancer patients receiving neoadjuvant treatment. BMC Cancer 2011; 11: 486

28 Untch M, Fasching PA, Konecny GE et al. Pathologic complete response after neoadjuvant chemotherapy plus trastuzumab predicts favorable survival in human epidermal growth factor receptor 2-overexpressing breast cancer: results from the TECHNO trial of the AGO and GBG study groups. J Clin Oncol 2011; 29: 3351-3357 
29 Untch M, Fasching PA, Konecny GE et al. PREPARE trial: a randomized phase III trial comparing preoperative, dose-dense, dose-intensified chemotherapy with epirubicin, paclitaxel and CMF versus a standarddosed epirubicin/cyclophosphamide followed by paclitaxel \pm darbepoetin alfa in primary breast cancer - results at the time of surgery. Ann Oncol 2011; 22: 1988-1998

30 Untch M, Loibl S, Bischoff J et al. Lapatinib versus trastuzumab in combination with neoadjuvant anthracycline-taxane-based chemotherapy (GeparQuinto, GBG 44): a randomised phase 3 trial. Lancet Oncol 2012; 13: 135-144

31 Untch M, Rezai M, Loibl S et al. Neoadjuvant treatment with trastuzumab in HER2-positive breast cancer: results from the GeparQuattro study. J Clin Oncol 2010; 28: 2024-2031

32 Untch M, von Minckwitz G, Konecny GE et al. PREPARE trial: a randomized phase III trial comparing preoperative, dose-dense, dose-intensified chemotherapy with epirubicin, paclitaxel, and CMF versus a standard-dosed epirubicin-cyclophosphamide followed by paclitaxel with or without darbepoetin alfa in primary breast cancer - outcome on prognosis. Ann Oncol 2011; 22: 1999-2006

33 von Minckwitz G, Eidtmann H, Loibl S et al. Integrating bevacizumab, everolimus, and lapatinib into current neoadjuvant chemotherapy regimen for primary breast cancer. Safety results of the GeparQuinto trial. Ann Oncol 2011; 22: 301-306

34 von Minckwitz G, Eidtmann $H$, Rezai $M$ et al. Neoadjuvant chemotherapy and bevacizumab for HER2-negative breast cancer. N Engl J Med 2012; 366: 299-309

35 von Minckwitz G, Jonat W, Fasching P et al. A multicentre phase II study on gefitinib in taxane- and anthracycline-pretreated metastatic breast cancer. Breast Cancer Res Treat 2005; 89: 165-172

36 von Minckwitz G, Rezai M, Loibl S et al. Capecitabine in addition to anthracycline- and taxane-based neoadjuvant treatment in patients with primary breast cancer: phase III GeparQuattro study. J Clin Oncol 2010; 28: 2015-2023

37 von Minckwitz G, Untch $M$, Nuesch $E$ et al. Impact of treatment characteristics on response of different breast cancer phenotypes: pooled analysis of the German neo-adjuvant chemotherapy trials. Breast Cancer Res Treat 2011; 125: 145-156

38 Fasching PA, Jud SM, Hauschild M et al. Anticancer activity of letrozole plus zoledronic acid as neoadjuvant therapy for postmenopausal patients with breast cancer: FEMZONE trial results. Cancer Res 2012; 72 (24 Suppl.): $123 \mathrm{~s}$

39 Cortazar P, Zhang L, Untch $M$ et al. Meta-analysis results from the collaborative trials in neoadjuvant breast cancer (CTNeoBC). Cancer Res 2012; 72 (24 Suppl.): $93 \mathrm{~s}$

40 Anders CK, Hsu DS, Broadwater $G$ et al. Young age at diagnosis correlates with worse prognosis and defines a subset of breast cancers with shared patterns of gene expression. J Clin Oncol 2008; 26: 3324-3330

41 Loibl S, Jackisch C, Gade S et al. Neoadjuvant chemotherapy in the very young 35 years of age or younger. Cancer Res 2012; 72 (24 Suppl.): $96 \mathrm{~s}$

42 Cameron D, Brown J, Dent $R$ et al. Primary results of BEATRICE, a randomized phase III trial evaluating adjuvant bevacizumab-containing therapy in triple negative breast cancer. Cancer Res 2012; 72 (24 Suppl.): $108 \mathrm{~s}$

43 Carmeliet P, Pallaud C, Deurloo RJ et al. Plasma (p) VEGF-A and VEGFR-2 biomarker (BM) results from the BEATRICE phase III trial of bevacizumab (BEV) in triple negative early breast cancer (BC). Cancer Res 2012; 72 (24 Suppl.): $321 \mathrm{~s}$

44 Lambrechts D, Claes B, Delmar P et al. VEGF pathway genetic variants as biomarkers of treatment outcome with bevacizumab: an analysis of data from the AViTA and AVOREN randomised trials. Lancet Oncol 2012; 13: 724-733

45 Lambrechts D, Lenz HJ, de Haas S et al. Markers of response for the antiangiogenic agent bevacizumab. J Clin Oncol 2013; 31: 1219-1230

46 Moebus V, Schneeweis A, du Bois A et al. Ten year follow-up analysis of intense dose-dense adjuvant ETC (epirubicin (E), paclitaxel (T) and cyclophosphamide (C)) confirms superior DFS and OS benefit in comparison to conventional dosed chemotherapy in high-risk breast cancer patients with $\geq 4$ positive lymph nodes. Cancer Res 2012; 72 (24 Suppl.): $97 \mathrm{~s}$

47 Aebi S, Gelber S, Lang I et al. Chemotherapy prolongs survival for isolated local or regional recurrence of breast cancer: the CALOR trial (Chemotherapy as Adjuvant for Locally Recurrent breast cancer; IBCSG 27-02, NSABP B-37, BIG 1-02). Cancer Res 2012; 72 (24 Suppl.): $96 \mathrm{~s}$
48 Davies C, Pan H, Godwin J et al. ATLAS - 10 v 5 years of adjuvant tamoxifen (TAM) in ER+ disease: Effects on outcome in the first and in the second decade after diagnosis. Cancer Res 2012; 72 (24 Suppl.): 89s

49 Metzger O, Giobbie-Hurder A, Mallon E et al. Relative effectiveness of letrozole compared with tamoxifen for patients with lobular carcinoma in the BIG 1-98 trial. Cancer Res 2012; 72 (24 Suppl.): 89 s

50 Luftner D, Lux MP, Maass N et al. Advances in breast cancer - looking back over the year. Geburtsh Frauenheilk 2012; 72: 1117-1129

51 Pivot X, Romieu G, Bonnefoi $H$ et al. PHARE trial results of subset analysis comparing 6 to 12 months of trastuzumab in adjuvant early breast cancer. Cancer Res 2012; 72 (24 Suppl.): 104s

52 Earl HM, Cameron DA, Miles D et al. PERSEPHONE: duration of trastuzumab with chemotherapy in women with HER2 positive early breast cancer. Cancer Res 2012; 72 (24 Suppl.): $557 \mathrm{~s}$

53 Di Leo A, Jerusalem G, Petruzelka L et al. Final analysis of overall survival for the phase III CONFIRM trial: fulvestrant $500 \mathrm{mg}$ versus $250 \mathrm{mg}$. Cancer Res 2012; 72 (24 Suppl.): 90 s

54 Baselga J, Campone M, Piccart $M$ et al. Everolimus in postmenopausal hormone-receptor-positive advanced breast cancer. N Engl J Med 2012; 366: 520-529

55 Piccart M, Baselga J, Noguchi S et al. Final progression-free survival analysis of BOLERO-2: a phase III trial of everolimus for postmenopausal women with advanced breast cancer. Cancer Res 2012; 72 (24 Suppl.): $492 \mathrm{~s}$

56 Finn RS, Crown JP, Lang I et al. Results of a randomized phase 2 study of PD 0332991, a cyclin-dependent kinase (CDK) 4/6 inhibitor, in combination with letrozole vs. letrozole alone for first-line treatment of ER+/HER2- advanced breast cancer (BC). Cancer Res 2012; 72 (24 Suppl.): $91 \mathrm{~s}$

57 Swain SM, Kim SB, Cortes J et al. Pertuzumab, trastuzumab, and docetaxel for HER2-positive metastatic breast cancer (CLEOPATRA study): overall survival results from a randomised, double-blind, placebo-controlled, phase 3 study. Lancet Oncol 2013; 14: 461-471

58 Baselga J, Cortés J, Im SA et al. Biomarker analyses in CLEOPATRA: A phase III, placebo-controlled study of pertuzumab in HER2-positive, first-line metastatic breast cancer (MBC). Cancer Res 2012; 72 (Suppl. 24): $103 \mathrm{~s}$

59 Hartkopf $A D$, Banys M, Krawczyk $N$ et al. Circulating tumor cells in early-stage breast cancer. Geburtsh Frauenheilk 2011; 71: 1067-1072

60 Jaeger BAS, Rack BK, Andergassen $U$ et al. Circulating tumor cells (CTC) may express HER2/neu in patients with early HER2/neu negative breast cancer - results of the German SUCCESS C trial. Cancer Res 2012; 72 (24 Suppl.): 215s

61 Sgroi DC, Sestak I, Zhang Y et al. Evaluation of prognostic and predictive performance of breast cancer index and its components in hormonal receptor-positive breast cancer patients: a TransATAC study. Cancer Res 2012; 72 (24 Suppl.): 248s

62 Dubsky P, Brase JC, Fisch $K$ et al. The EndoPredict score identifies late distant metastases in ER+/HER2- breast cancer patients. Cancer Res 2012; 72 (24 Suppl.): $101 \mathrm{~s}$

63 Cheang MC, Chia SK, Voduc D et al. Ki67 index, HER2 status, and prognosis of patients with luminal B breast cancer. J Natl Cancer Inst 2009; 101: 736-750

64 Schmidt M, Fasching PA, Beckmann MW et al. Biomarkers in breast cancer - an update. Geburtsh Frauenheilk 2012; 72: 819-832

65 Denkert C, Blohmer JU, Müller BM et al. Ki67 levels in pretherapeutic core biopsies as predictive and prognostic parameters in the neoadjuvant GeparTrio trial. Cancer Res 2012; 72 (24 Suppl.): 102s

66 Yamauchi H, Nakagawa C, Yamashige S et al. Societal economics of the 21-gene Recurrence Score ${ }^{\circledR}$ in estrogen receptor-positive early-stage breast cancer in Japan. Cancer Res 2012; 72 (24 Suppl.): 458 s

67 Blohmer JU, Rezai M, Kummel S et al. Using the 21-gene assay to guide adjuvant chemotherapy decision-making in early-stage breast cancer: a cost-effectiveness evaluation in the German setting. J Med Econ 2013; 16: 30-40

68 Jacobs VR, Augustin D, Wischnik A et al. Analysis of test-therapy concordance for biomarkers UPA and PAI-1 in primary breast cancer in clinical hospital routine: results of a prospective multi-center study at certified breast cancers in Germany. Cancer Res 2012; 72 (24 Suppl.): $455 \mathrm{~s}-456 \mathrm{~s}$

69 Conter HJ, Conter D, Wolff RA et al. The benefit of targeted therapeutics in medical oncology since the development of trastuzumab. Cancer Res 2012; 72 (24 Suppl.): 456s 
70 Xie J, Diener M, De G et al. Budget impact analysis of everolimus for estrogen receptor positive, human epidermal growth factor receptor-2 negative metastatic breast cancer patients in the United States. Cancer Res 2012; 72 (24 Suppl.): 457s

71 Wolff AC, Hammond ME, Schwartz JN et al. American Society of Clinical Oncology/College of American Pathologists guideline recommendations for human epidermal growth factor receptor 2 testing in breast cancer. J Clin Oncol 2007; 25: 118-145

72 Sauter G, Lee J, Bartlett JM et al. Guidelines for human epidermal growth factor receptor 2 testing: biologic and methodologic considerations. J Clin Oncol 2009; 27: 1323-1333

73 Arbeitsgemeinschaft für Gynäkologische Onkologie e.V.; Kommission Mamma. Diagnostik und Therapie von Patientinnen mit primärem metastasiertem Brustkrebs. Version 2013.10. www.ago-online.de; 2013
74 Martin M, Loibl S, von Minckwitz G et al.; on behalf of GEICAM (Spanish Breast Cancer Research Group); GBG (German Breast Group). Phase III trial evaluating the addition of bevacizumab to endocrine therapy as first-line treatment for advanced breast cancer - first efficacy results from the LEA study. Cancer Res 2012; 72 (24 Suppl.): 91s-92s

75 Kaufman PA, Awada A, Twelves C et al. A Phase III, open-label, randomized, multicenter study of eribulin mesylate versus capecitabine in patients with locally advanced or metastatic breast cancer previously treated with anthracyclines and taxanes. Cancer Res 2012; 72 (24 Suppl.): 109s

76 Kreienberg R, Albert U-S, Follmann M et al. Interdisciplinary GoR level II guidelines for the diagnosis, therapy and follow-up care of breast cancer - Short version - AWMF Registry No.: 032-0450L. Geburtsh Frauenheilk 2013; 73: 556-583

Deutschsprachige Zusatzinformationen online abrufbar unter: www.thieme-connect.de/ejournals/toc/gebfra. 